\title{
Manganese mineralogy and diagenesis in the sedimentary rock record
}

Jena E. Johnson $^{1}{ }^{*}$, Samuel M. Webb ${ }^{2}$, Chi Ma ${ }^{1}$, Woodward W. Fischer ${ }^{1}$

${ }^{1}$ Division of Geological and Planetary Sciences, California Institute of Technology, Pasadena CA 91125

${ }^{2}$ Stanford Synchrotron Radiation Lightsource, Stanford University, Menlo Park, CA 94025

*corresponding author, jena@gps.caltech.edu; (626)395-6465

\begin{abstract}
Oxidation of manganese(II) to manganese(III,IV) demands oxidants with very high redox potentials; consequently, manganese oxides are both excellent proxies for molecular oxygen and highly favorable electron acceptors when oxygen is absent. The first of these features results in manganese-enriched sedimentary rocks (manganese deposits, commonly $\mathrm{Mn}$ ore deposits), which generally correspond to the availability of molecular oxygen in Earth surface environments. And yet because manganese reduction is promoted by a variety of chemical species, these ancient manganese deposits are often significantly more reduced than modern environmental manganese-rich sediments. We document the impacts of manganese reduction and the mineral phases that form stable manganese deposits from seven sedimentary examples spanning from modern surface environments to rocks over 2 billion years old. Integrating redox and coordination information from synchrotron X-ray absorption spectroscopy and X-ray microprobe imaging with scanning electron microscopy and energy and wavelength-dispersive spectroscopy, we find that unlike the Mn(IV)-dominated modern manganese deposits, three manganese minerals dominate these representative ancient deposits: kutnohorite $\left(\mathrm{CaMn}\left(\mathrm{CO}_{3}\right)_{2}\right)$, rhodochrosite $\left(\mathrm{MnCO}_{3}\right)$, and braunite $\left(\mathrm{Mn}(\mathrm{III})_{6} \mathrm{Mn}(\mathrm{II}) \mathrm{O}_{8} \mathrm{SiO}_{4}\right)$. Pairing these mineral and textural observations with previous studies of manganese geochemistry, we develop a paragenetic model of post-depositional manganese mineralization with kutnohorite and calcian rhodochrosite as the earliest diagenetic mineral phases, rhodochrosite and braunite forming secondarily, and later alteration forming Mn-silicates.
\end{abstract}

\section{INTRODUCTION}

Manganese oxides are critical environmental materials as powerful oxidants, as scavengers of important trace elements and reactive oxygen species, and as electron acceptors for anaerobic respiration (Myers and Nealson, 1988; Tebo et al., 2005). Manganese is both the third most abundant transition metal in Earth's crust and has the largest number of oxidation states of $3 \mathrm{~d}$ row elements (Armstrong, 2008), and so consequently the manganese cycle-both modern and ancient-involves multiple redox conversions.

Manganese is present exclusively in divalent form in a wide range of igneous minerals where it substitutes for iron (Post, 1999). Ultrabasic, basaltic, granitic and syenitic igneous rocks average at about $0.1 \% \mathrm{Mn}(\mathrm{II})$ (Turekian and Wedepohl, 1961). Thus silicate weathering provides a substantial source of $\mathrm{Mn}^{2+}$ to surface and ground waters, especially since $\mathrm{Mn}$ (II) is highly soluble - even more so than iron (Gross, 1965; Post, 1999). $\mathrm{Mn}^{2+}$ is also sourced from seafloor hydrothermal vent fluids, at high but variable concentrations ranging from hundreds to thousands of micromoles per kilogram (Von Damm, 1990). 
To concentrate Mn into significant sedimentary deposits, manganese needs to be oxidized to Mn(III) or Mn(IV) (Calvert and Pedersen, 1996). These ions form oxyhydroxide minerals that are deposited in sediments (Calvert and Pedersen, 1996; Armstrong, 2008). Unlike iron, manganese does not readily form sulfides, but is only insoluble in its oxidized forms (Van Cappellen et al., 1998; Maynard, 2010). Thus, the presence of significant manganese deposition in the sedimentary record should reflect the history of manganese oxidation.

However, there are a couple exceptions to this general relationship that manganese enrichment in the sediments signifies manganese oxidation. When there are high levels of soluble $\mathrm{Mn}^{2+}$, this divalent ion can substitute for $\mathrm{Ca}^{2+}$ in authigenic carbonate phases. In Phanerozoic carbonates, Mn concentration is often used as a characteristic marker for secondary alteration (Brand and Veizer, 1980); this is due to sedimentary pore waters becoming enriched in $\mathrm{Mn}^{2+}$ due to the reduction and dissolution of $\mathrm{Mn}(\mathrm{IV})$ oxides (Calvert and Pedersen, 1996; Van Cappellen et al., 1998) and the elevated Mn concentrations in hydrothermal fluids (Von Damm, 1990). While elevated $\mathrm{Mn}$ in carbonates usually relates to alteration, primary well-preserved carbonates from the Archean Eon (4 billion years ago (Ga) to $2.5 \mathrm{Ga}$ ) have elevated $\mathrm{Mn}$ levels - up to $1 \% \mathrm{Mn}$ rather than typical Phanerozoic carbonates of 10-50 ppm in well-preserved carbonates (Veizer, 1978; Brand and Veizer, 1980; Holland, 1984; Beukes, 1987; Komiya et al., 2008; Fischer and Knoll, 2009). These anomalous Mn-enriched carbonate platforms occur because the oceans during this time were anoxic and able to concentrate soluble $\mathrm{Mn}^{2+}$ to relatively high levels (estimated to be as much as 3 to $7 \mu \mathrm{m}$, (Holland, 1984)). Karst weathering, the near-surface dissolution of carbonates from interaction with meteoritic waters, of Archean (Mn-bearing) carbonates can lead to further supergene concentration of $\mathrm{Mn}$ as the carbonate is dissolved and $\mathrm{Mn}^{2+}$ is oxidized. This process can produce small but economically meaningful Mn ores after the rise of oxygen such as the Postmasburg and Woodie Woodie Mn deposits (Gutzmer and Beukes, 1996a; Jones et al., 2013).

The high $\mathrm{Mn}^{2+}$ concentration in Archean seawater was directly related to the lack of $\mathrm{Mn}$ oxidation before the rise of oxygen, approximately 2.3 billion years ago. There is a very limited set of processes and oxidants able to oxidize manganese due to its high redox potential (Tebo et al., 2004). Low levels of manganese oxidation is possible from reactions with UV light, but this is suppressed in the presence of $\mathrm{Fe}^{2+}$ or other reductants (Anbar and Holland, 1992). Manganese is oxidized phototrophically during the biosynthesis of the water-oxidizing complex of Photosystem II in Cyanobacteria, plants and algae (Tamura and Cheniae, 1987; Büchel et al., 1999). However, this phototrophic Mn oxidation is not thought to produce environmentallysignificant manganese oxides (Madison et al., 2013) and no solely manganese-oxidizing photosystem has been documented in modern phototrophs (White, 2007). With a possible evolutionary exception (Johnson et al., 2013), Mn(II) is only oxidized at meaningful rates by molecular oxygen or $\mathrm{O}_{2}$-derived species like superoxide (Calvert and Pedersen, 1996; Post, 1999; Tebo et al., 2004; Morgan, 2005; Dick et al., 2009; Hansel et al., 2012), so the presence of manganese(III,IV) oxides in sedimentary rocks can indicate free oxygen was once present in the environment.

Due to the high-potential redox chemistry of $\mathrm{Mn}$, the geologic record of manganese deposits should reflect ancient oxygen availability and the paleo-environmental chemistry (Maynard, 2010). In Fig. 1, we present an updated compilation of Mn deposits through geologic time, and 
also plot size estimates of each terrestrial deposit (Fig. 1, Table 1). The lack of significant Archean Mn deposits is striking, as is the massive Hotazel deposit at around 2.22 Ga. Several previous compilations have included small Archean manganese deposits (Roy, 2006; Maynard, 2010), but because these appear to be derived from later weathering of Archean carbonate strata (which contain elevated $\mathrm{Mn}(\mathrm{II})$ ) we do not include them as in some cases the timing of the weathering is unknown (Roy, 2006). It is interesting that the world's largest terrestrial manganese deposit - estimated to be 13,500 million metric tons (Taljaardt, 1982) —was deposited soon after oxygen was introduced into the atmosphere and oceans around $2.3 \mathrm{Ga}$ (Kirschvink et al., 2000; Bekker et al., 2004; Hoffman, 2013). Manganese indeed appears to be associated with the presence of environmental oxygen, since manganese deposits post-2.3 Ga are common (Fig.1). Thus, Mn deposits provide insight into redox processes operating in surface environments on Earth.

To understand the genesis of Mn deposits in greater mechanistic detail, we chose to carefully investigate representative samples from seven globally-distributed manganese deposits spanning from the modern to 2.41 billion years ago. We coupled petrography and sedimentary geology using optical and electron microscopy with microscale X-ray absorption spectroscopy (XAS) imaging to better understand the manganese phases present and the processes that produced them. From previous surveys of geologic manganese deposits, it is clear there are significant manganese mineral variations in ancient deposits; notably, the redox state of manganese varies in these minerals from Mn(II) to Mn(III) to Mn(IV) (Okita et al., 1988; Roy, 2006; Maynard, 2010). Maynard (2010) summarized the major minerals in manganese deposits as braunite, a mixed valence $\mathrm{Mn}(\mathrm{III} / \mathrm{II})$ oxide, and rhodochrosite, a $\mathrm{Mn}$ carbonate salt. He found that rhodochrosite dominated in sedimentary environments, braunite in volcanic deposits, and other Mn oxides were found in karstic and supergene environments (Maynard, 2010). Within sedimentary deposits, he proposed rhodochrosite was a primary or early diagenetic (secondary) Mn mineral and that other Mn silicates and oxides (like braunite) arose during late diagenesis, metamorphism or supergene alteration, with the evidence for this hypothesis arising from ${ }^{13} \mathrm{C}$ depleted stable carbon isotopes in rhodochrosite in the major Mn deposits (Maynard, 2010).

We tested this hypothesis of manganese mineral paragenesis using classic sedimentological and petrographic observations at the scale of textures and mineral grains. We applied new microscale analyses to a range of sedimentary deposits to identify the sequence of mineralogical changes that occur to manganese deposits from deposition through early diagenesis and metamorphism to near-surface oxidative weathering. These observations of manganese mineralization enable us to infer the likely primary precipitates that concentrated manganese in ancient sediments and the post-depositional processes that subsequently altered mineralogy and stabilized the manganese in the rock record.

\section{METHODS}

Understanding the mineralogy, geochemistry and petrogenesis of manganese-rich sedimentary rocks presents several challenges: the deposits are large but the materials are complex at fine scales, and thus analysis requires both microscale observations and basin-scale integration. An ideal way to determine redox state and mineral host at multiple scales is XAS coupled to light and electron microscopy techniques. Light and electron microscopy are crucial for understanding phase relationships as observations can be made on the same scale as mineralogical textures, 
allowing one to distinguish more primary minerals from cross-cutting or vein-filling phases. Synchrotron-based XAS is a powerful method that measures the chemical properties of a specific element (or elements) within a sample. The absorption spectrum is sensitive to the local electronic and bonding environment of the absorbing element, and thus the spectrum indicates the absorbing atom's oxidation state and coordination environment. An X-ray microprobe can be used to map the chemical information of a specific element even in complex matrices, complementing the sedimentological relationships observed microscopically.

\subsection{Sample acquisition and preparation}

We obtained samples from seven geologic time periods and geographic locations to comprise a sample suite representing manganese deposits through geologic time. Geologic details on each sample site can be found in Appendix A. We produced ultrathin $(\sim 15-20 \mu \mathrm{m})$ sections from rock billets cut from each of our study sites and analyzed them using a range of complementary methods. Ultrathin sections were prepared by High Mesa Petrographics. For most samples, we also powdered $200 \mathrm{mg}$ using a microdrill or an agate mortar and pestle to make bulk measurements. Samples were acquired from a variety of sources and localities, and described in supplemental information.

\subsection{Analytical methods}

We examined our thin sections with transmitted and reflected light microscopy on a Leica polarizing microscope to observe petrographic textures. We used scanning electron microscopy and energy dispersive spectrometry (SEM-EDS) to document small-scale relationships between textures and measure elemental distributions and abundances. The Caltech Geological and Planetary Sciences Division Analytical Facility houses a Zeiss 1550VP Field Emission SEM equipped with an Oxford X-Max $80 \mathrm{~mm}^{2}$ SDD EDS system. We produced high-resolution images in backscatter detector imaging mode to enhance compositional contrast, as areas with higher average atomic numbers will generate more backscattered electrons. We used EDS to produce point elemental measurements and X-ray maps of regions of interest. Quantitative elemental analysis provides relative accuracy of better than $5 \%$.

We also used synchrotron-based XAS to identify mineral hosts and distinguish redox states clearly by comparison to a wide range of standards (Fig. 2; Fig A1). Bulk powders of the rocks were measured for overall mineralogy and redox state to extend data to larger scales, but thin sections of the rock were also analyzed using a spatially-resolved XAS microprobe to understand small-scale relationships and constrain the timing of precipitation of different phases. The microprobe measures X-ray fluorescence over the Mn K-edge on a micron scale to obtain an Xray absorption spectrum at targeted points. Furthermore, the microprobe can produce 'redox images' of a sample by measuring the X-ray fluorescence across a sample at a combination of diagnostic energies through the absorption edge of interest (Mayhew et al., 2011; Webb, 2011; Johnson et al., 2013). These multiple-energy maps are subsequently reduced by fitting to internal standards to produce a redox map, thereby creating an image (with a pixel size as small as the $\sim 2$ $\mu \mathrm{m}$ beam) of variations in phase and/or redox state of a given element within a sample.

We measured these powder and thin section samples at the Stanford Synchrotron Radiation Lightsource (SSRL). We used two imaging beam lines: beam line 10-2 and beam line 2-3. These experimental stations cover a wide range of beam sizes (2-100 microns) and incident X-ray 
energies (2-20 keV). With beam line 10-2, we use the larger beam size and high photon flux to perform rapid screening of thin sections. These qualities allow us to produce coarse-scale maps of a wide range of samples across the deposit volume, and determine representative domains to target with smaller-scale analysis. Beam line 10-2 maps were generated using a Vortex SII International Silicon drift detector to collect X-ray fluorescence signals for each $\sim 30-100 \mu \mathrm{m} \mathrm{X}$ 30-100 $\mu \mathrm{m}$ pixel. Subsequently, at beam line 2-3, we mapped chosen regions of interest at four to five energies chosen to have redox- or mineral-distinctive X-ray absorptions $(6551 \mathrm{eV}, 6557 / 8$ $\mathrm{eV}, 6562 \mathrm{eV}, 6573 / 5 \mathrm{eV}$ for $\mathrm{Mn})$. These higher resolution maps at $\sim 2-5 \mu \mathrm{m}$ were produced with a $2 \mu \mathrm{m}$ beam using Kirkpatrick Baez mirrors for focusing, with X-ray fluorescence signals collected on a Vortex SII International Silicon drift detector. We measured X-ray absorption near edge structure (XANES) spectra at $2 \mu \mathrm{m}$ points in these maps to produce internal standards and to confirm best-fit assignments. When available, we additionally measured bulk sample powder at beam line 4-1 to obtain the spectra for average manganese redox state and mineral phase. At beam line 4-1, we collected X-ray absorption spectra in both transmission and fluorescence mode using a Lytle detector for fluorescence detection. The energy of the experiment was selected using a $\operatorname{Si}(220) \Phi=90$ crystal. We used a collimating mirror to help reduce harmonics in the beam and duplicates were run on all spectra for XANES scanning from 6310 to $7108 \mathrm{eV}$. Samples were prepared as monolayers of bulk sample powder on tape. All beam lines were calibrated using the pre-edge peak of a potassium permanganate $\left[\mathrm{KMnO}_{4}\right]$ standard defined as $6543.34 \mathrm{eV}$.

Several sections contained previously unidentified minerals in terms of Mn XAS spectra and Xray EDS spectra. Two were small $\mathrm{Mn}(\mathrm{IV})$ oxides identified from our Hotazel representative section and one was an abundant Mn(II) mineral from our Santa Cruz section. These and other samples were further examined using SEM-based electron backscatter diffraction (EBSD) and on the electron microprobe to quantify elemental abundance. Samples for EBSD measurements were additionally polished using a vibroration polisher. EBSD patterns of minerals were indexed using crystal structure databases for identification and/or confirmation of mineral phase. Quantitative measurements of points from manganese-bearing carbonates and from minerals unidentified by XAS spectrometry were made using a JEOL JXA-8200 advanced Electron Probe Microanalyzer (EPMA). This instrument is part of the Geological and Planetary Sciences Division Analytical Facility and is equipped with five wavelength dispersive X-ray spectrometers (WDS) and a tungsten electron source. The precision for elements were as follows for carbonates: $\mathrm{Mn}(0.6 \%), \mathrm{Ca}(0.69 \%), \mathrm{Mg}(1.5 \%)$, and $\mathrm{Fe}(1.1 \%)$. For Hotazel oxides and the Santa Cruz Formation silicate, one-sigma precision was slightly different due to the different minerals: Al (1.9\%), Fe (1.7\%), Mg (1.7\%), Ca (1.1\%), Na (5.2\%), K (5.3\%), Mn (0.27\%), O $(0.28 \%)$. Detection limits were 0.04 or better for all eight elements. The $\mathrm{Mn}(\mathrm{II})$ mineral from the Santa Cruz section was further analyzed using Raman spectroscopy, a visible light (514nm) vibrational spectroscopic technique that probes molecular symmetry, using the Raman detector in the Mineralogy lab at Caltech.

\section{RESULTS}

We selected to study a range of manganese deposits, from a variety of paleoenvironments and geologic intervals, to capture the mineralogical and textural diversity of manganese-enriched formations (Fig. 1, arrows). While there is significantly more mineralogical richness associated with hydrothermal, metamorphic, and supergene manganese deposits, we focused this study on 
the best-preserved samples we could acquire from each of these deposits. We note that nearly all ancient rocks have been affected by late diagenetic, metamorphic and metasomatic processes, and our observations highlight the key changes that have taken place. By combining traditional sedimentology and advanced microscale techniques, we can piece together a common paragenetic sequence of mineral formation in Mn-rich sediments.

Modern manganese deposits and ancient manganese-enriched rocks from 3 million years ago (Ma) to $2415 \mathrm{Ma}$ were probed for overall manganese redox state, and meso- and micro-scale manganese mineral relationships. In seeking to understand the processes that alter manganese minerals through time, we developed efficient strategies to understand manganese mineralogy using synchrotron-based methods and synthesized a theory of manganese stabilization in the rock record. We also made fundamental observations documenting the important phases and reduction processes that occur in ancient manganese deposits, as all ancient deposits are significantly more reduced (Mn(II) or $\mathrm{Mn}(\mathrm{II} / \mathrm{III})$ phases) than modern deposits (Mn(IV) phases).

\subsection{Modern manganese deposits}

Our calibration point for modern (or very recent) manganese deposition was a deep-sea manganese nodule collected from the ocean floor. The deep-sea manganese nodule (Fig. 3) was collected from the South Pacific Gyre, an extremely oligotrophic area of the ocean where sedimentary organic fluxes are low and pore fluid oxygen levels remain high-within 150 to 250 $\mu \mathrm{M}$ of $\mathrm{O}_{2}$ - to the basement (Ingle et al., 1990). The thin section domain prepared for chemical imaging samples a radial portion of the nodule, which is approximately $30 \mathrm{~mm}$ from the surface of initial growth (central orange lithic fragment nucleus in Fig. 3) to the outermost 'active' layer. Manganese nodules constitute a distinct style of manganese mineralization that make them imperfect analogs for many shallower marine deposits in the geological record because these nodules typically accumulate over exceptionally low timescales - this extends in certain cases to millions of years of time captured within a single nodule, promoting their use as archives of past seawater conditions (e.g., Horner et al., 2015). However, the outer layers of this contain Mn phases only recently mineralized. Following a recent estimate of nodule growth rates (113 $\mathrm{mm} / \mathrm{Ma}$, González et al., 2012), the radius would date the innermost manganese layers to 270,000 years ago. Other growth rate estimates (1-5 mm/Ma, Hein et al., 2000) would place the central manganese layers as old as 30 million years old, suggesting only outer layers could be used as a recent calibration point. Thus despite their unique mode of accumulation, the manganese nodule sample offers a useful measure of the Mn-bearing phases that first accumulate $\mathrm{Mn}$ in marine sediments.

The textures of this deep-sea manganese nodule, best observed under SEM, are quite striking (Fig. 3). The manganese presents as thin layers of isopachous cements with abundant inclusions of aluminosilicate detrital minerals that together manifest in a stromatolitic morphology. Brighter manganese oxide bands alternate with mixed manganese and iron oxides, and on a micron-scale, the bands vary from very finely laminated to porous (Fig. 3). The manganese oxide phases are sub-micrometer disordered material intermixed with other phases in a replacive texture, and as expected for recently precipitated materials, they are either amorphous or too finely crystalline to produce a discernible diffraction pattern via EBSD (Fig A2). 
By synchrotron analyses, the nodule consists of solely Mn(IV)-oxide from the nodule center to the outer layers. Bulk samples and thin sections of all these modern-day manganese deposits were imaged using synchrotron-based redox and mineral mapping. Fig. 3 shows manganese abundance as mapped on beam line 10-2 and reduced from multiple energy maps using fitting to produce a manganese redox map (see Methods). We also mapped smaller, representative areas at beam line 2-3 at a higher resolution and measured X-ray absorption spectra of specific points (Fig. 3). X-ray absorption spectra from points and bulk powders are shown on the bottom right with the most similar standard spectra. For this modern manganese deposit, birnessite was the best spectral match and both redox mapping and point spectra indicate manganese is dominantly present as Mn(IV) oxides.

While this South Pacific manganese nodule may not be the ideal calibration point for modern manganese deposits due to its unique process sedimentology and environment, prior studies have also determined that $\mathrm{Mn}(\mathrm{IV})$ oxides like birnessite is the dominant mineral formed by a range of contemporary Mn oxidation and precipitation processes (Bargar et al., 2000; Tebo et al., 2004; Bargar et al., 2005; Webb et al., 2005). From environmental samples, the ultimate product of $\mathrm{Mn}^{2+}$ oxidation in the Saanich Inlet, the Black Sea, desert varnish, lake sediments, and Pacific ocean sediments is $\mathrm{Mn}(\mathrm{IV})$-dominated, poorly crystalline, layered oxides (Murray et al., 1985; Wehrli et al., 1995; McKeown and Post, 2001; Tebo et al., 2004). As birnessite appears to be the primary precipitate from Mn oxidation over a range of environments and oxidation processes, we conclude that layered $\mathrm{Mn}(\mathrm{IV})$ oxides are the most common stable Mn phase to first accumulate in sediments.

\subsection{Ancient manganese deposits}

To explore how manganese ends up stabilized in the rock record and probe which processes have affected the Mn mineralogy, we examined five Mn-enriched sedimentary deposits ranging from poorly indurated sedimentary rocks in ocean drill cores (3 to $11 \mathrm{Ma}$ ) to the earliest significant deposit of $\mathrm{Mn}$ in the rock record $(2.4 \mathrm{Ga})$. Most of these ancient deposits are now significant terrestrial Mn ores and are highlighted in Fig. 1. These Mn deposits not only cover an enormous expanse of time, but they also capture a variety of both modern and ancient environments: samples were acquired from South Africa, Brazil, Mexico, and the Japan Sea, and their depositional environments have been reconstructed as varying from shallow marine to continental rift basin to deep ocean trench. Beginning with the most recent deposit and proceeding back through time, we describe the geologic setting, visual and electron microscopic observations and finally the X-ray absorption measurements for each of these deposits. These data are also summarized in Table 2.

\subsubsection{Japan Sea Drill Core}

To examine the petrogenesis of manganese in this deposit, we acquired several samples from the ODP Site 799 core drilled into organic carbon-rich sediments deposited in a failed rift basin in the Japan Sea (Matsumoto, 1992). Three samples (196 m, 326 m, $502 \mathrm{~m}$, Pliocene to late Miocene in age) were unlithified, but the deepest sample at $533 \mathrm{~m}$ (from the Late-Middle Miocene boundary, approximately $11 \mathrm{Ma}$ ) was sufficiently consolidated to make a thin section that preserved textures. Our thin section of core material at $533 \mathrm{~m}$ comprised of tan and darker brown carbonates with scattered opaque minerals (Fig. 4). The top of the section was dominated by darker carbonates while the bottom half had a higher abundance of lighter tan carbonates, but 
both were patchily distributed throughout the section (Fig. 4). SEM observations indicated the tan carbonates were coarsely crystalline ferrous magnesium carbonates, which appear yelloworange under transmitted light and a slightly darker grey in SEM photos. These are labeled $(\mathrm{Mg}, \mathrm{Fe}) \mathrm{CO}_{3}$ but this represents a range of EDS measurements which were $\mathrm{Mg}_{0.37-0.44} \mathrm{Fe}_{0.32-}$ ${ }_{0.37} \mathrm{Mn}_{0.1-0.17} \mathrm{Ca}_{0.09-0.14} \mathrm{CO}_{3}$. These coarse magnesian crystals have brighter rims, which we measured to be iron-enriched, with formulas of $\mathrm{Fe}_{0.44-0.52} \mathrm{Mg}_{0.22-0.25} \mathrm{Mn}_{0.15-0.21} \mathrm{Ca}_{0.08-0.11} \mathrm{CO}_{3}$. The top half of the sample and a small domain at the bottom, which appear darker in transmitted light and brighter in SEM photos, are much more manganese-enriched, and these areas have clusters of finer-grained calcium and manganese carbonates. In the top half of the section, we observed manganoan calcium carbonate similar to kutnohorite with formulas of $\mathrm{Ca}_{0.38-0.52} \mathrm{Mn}_{0.29-0.41} \mathrm{Mg}_{0.12-}$ ${ }_{0.19} \mathrm{Fe}_{0.03-0.06} \mathrm{CO}_{3}$. These finer-grained carbonate clusters were surrounded by the coarser-grained magnesian carbonates (Fig. 4). Upon close examination, the small dark brown spot at the bottom of the section is a combination of high-backscatter and low-backscatter minerals. Indeed, we found examples of both crystalline and finer-grained kutnohorite-like carbonates similar to the top half of the section, but these display rims and crystalline masses of a calcian rhodochrosite as well. This rhodochrosite had a formula range of $\mathrm{Mn}_{0.68-0.74} \mathrm{Ca}_{0.21-0.25} \mathrm{Mg}_{0.03-0.05} \mathrm{Fe}_{0.01-0.02} \mathrm{CO}_{3}$. Both cross-cutting relationships and the finest-grained carbonates imply that the manganoan calcium carbonate phases were produced early during sedimentary diagenesis, suggesting the precipitating fluids were both calcium- and manganese-rich. The coarser ferrous magnesium carbonate crystals suggest later recrystallizing fluids were magnesium and iron rich, and the bright iron-rich rims of these crystals points to an even later introduction of more iron-enriched fluids. Texturally the rhodochrosite too appears to be tied to later diagenetic processes, either from manganese-rich fluids or recrystallization and redistribution of calcium and manganese from earlier manganoan calcite precipitates.

We measured all four samples for bulk powder XAS and imaged the $533 \mathrm{~m}$ sample for manganese mineralogy and redox information (Fig. 4). One sample, IODP $326 \mathrm{~m}$, had a very weak absorption signal due to very low levels of manganese, and the spectra was difficult to uniquely assign other than observing a Mn(II) peak. The other samples were more clearly associated with the Mn-rich carbonate zones previously described and contain a mixture of approximately kutnohorite $\left(\mathrm{CaMn}\left(\mathrm{CO}_{3}\right)_{2}\right)$ and rhodochrosite $\left(\mathrm{MnCO}_{3}\right)$ (Matsumoto, 1992). By X-ray mapping, manganese was present exclusively as $\mathrm{Mn}(\mathrm{II})$ in different carbonate phases; bright minerals observed previously (Matsumoto, 1992) were iron sulfides, not Mn oxides. Multiple-energy X-ray fitting showed a dominance of kutnohorite-like carbonates from the top of the section, similar to results from the SEM, and a mixture of rhodochrosite and kutnohorite from the bottom manganese-enhanced domain. This hot spot shows a similar mixed pattern of rhodochrosite and kutnohorite in both light and dark grey backscatter on the SEM and the mapped kutnohorite/rhodochrosite distribution from XAS.

\subsubsection{Mexican Molango Deposit}

We examined a variety of samples from the Upper Jurassic-age Molango Mn-rich strata deposited at the base of the Kimmeridgian Taman Formation in a shallow marine carbonate platform shelf on a slowly subsiding basin (Scott, 1984; Okita, 1992). We mapped manganese speciation and measured XAS and SEM-EDS spectra on seven samples from throughout the Molango deposit from the Tetzintla section (T1) and the Acoxcatlan section (Aco) (Okita and Shanks, 1992) (Figs. 5, A3). From microscale textures of one ore zone sample on the SEM, Aco 
$2.4 \mathrm{~m}$, we observed a variety of phases rather than only rhodochrosite as Okita (1992) had previously determined. SEM analyses showed three phases: blocky crystals of ferrous rhodochrosite $\left(\mathrm{Mn}_{0.69} \mathrm{Fe}_{0.16} \mathrm{Ca}_{0.1} \mathrm{Mg}_{0.04} \mathrm{CO}_{3}\right)$, dark pockets of potentially the original matrix $\left(\mathrm{Ca}_{0.55} \mathrm{Mn}_{0.24} \mathrm{Fe}_{0.14} \mathrm{Mg}_{0.07} \mathrm{CO}_{3}\right)$, and bright rhodochrosite cements (bright white, $\mathrm{Mn}_{0.93} \mathrm{Ca}_{0.06} \mathrm{Fe}_{0.01} \mathrm{CO}_{3}$ ) (Fig. 5). Although the highly recrystallized nature of the Molango deposit carbonates makes observing consistent cross-cutting relationships challenging, the extremely high Mn content (up to $93 \%$ of cations) of the cements suggests secondary precipitation of later fluids enriched carbonates in $\mathrm{Mn}$, and that perhaps the manganoan calcium carbonates reflect the earliest sedimentary phase. XAS spectra showed rhodochrosite in the Mn ore zone (at $0-9 \mathrm{~m}$ ) consistent with previous reports (Okita, 1992; Okita and Shanks, 1992), transitioning to a mixture of kutnohorite (about $71 \%$ by linear combination fitting of spectral end members) and rhodochrosite (roughly $29 \%$ ) at $19 \mathrm{~m}$ and then only kutnohorite well above the ore zone. We also mapped three representative thin section samples in detail for redox state and speciation on the X-ray microprobe (Figs. 5, A3). These samples are dominantly rhodochrosite with small patches of kutnohorite in ore zone samples (Aco 0m and 2.4m, Figs. 5, A3), consistent with observations from the SEM-EDS. When mapping for carbonate speciation in overlying non-ore samples, we found dominantly kutnohorite (T1 26.5m, Fig. A3), similar to previous results (Okita et al., 1988; Okita and Shanks, 1992). The highly recrystallized nature of the ore zone sample under SEM (Fig. 5) indicates that the ore zone may have undergone significant hydrothermal and/or metamorphic alteration.

\subsubsection{Brazilian Santa Cruz deposit}

The Neoproterozoic Santa Cruz Formation hosts manganese and iron formation in an ancient continental rift basin (Urban et al., 1992). While the best manganese ore comes from surfaceweathered supergene hilltop caps or hydrothermally-altered zones along faults (Klein and Ladeira, 2004), we focused on well-preserved underground mine samples since weathering horizons in this region are very deep (Vasconcelos, 1999). We obtained one thin section sample and two bulk powder samples from the Brazilian Santa Cruz Formation. The thin section sample (SD92.11) came from over $2.5 \mathrm{~km}$ into an underground manganese mine at Urucum, and was collected away from faults or exposed surfaces. Thus, it provides a well-preserved example of the Santa Cruz Formation mineralogy. It is derived from the second stratigraphic manganese layer $(\mathrm{Mn} 2)$ from the base of the formation, which is the largest of the four layers (Urban et al., 1992). Another sample, a powdered sample also from the second manganese layer (SD92.07), was collected $\sim 1 \mathrm{~km}$ into the Urucum underground manganese mine, but along a fault.

SEM observations of the manganese-rich strata from the Santa Cruz Formation reveals that even the best-preserved materials contain a remarkably complex (compared to other deposits) assemblage of $\mathrm{Mn}$ minerals. While braunite $\left(\mathrm{Mn}(\mathrm{III})_{6} \mathrm{Mn}(\mathrm{II}) \mathrm{SiO}_{12}\right)$, rhodochrosite, and kutnohorite are present, and confirmed via EBSD (Figs. 6, A1), there were other Mn minerals that were more difficult to identify (Figs. 6, A4). In bulk XAS, the sample from the fault zone best matched cryptomelane or possibly birnessite, confirming this is a prevalent mineral in the formation and suggesting that the faults through the Santa Cruz Formation have introduced oxidizing fluids to the rock surrounding the faults. However, the subsurface sample collected away from the surface and any faults was comprised of only $\mathrm{Mn}$ (II) and Mn(III) minerals by Xray mapping, with four distinctive minerals identified using our point spectra (Fig. 6). The $\mathrm{Mn}(\mathrm{III})$ minerals are mainly braunite $\left[\mathrm{Mn}(\mathrm{III})_{6} \mathrm{Mn}(\mathrm{II}) \mathrm{O}_{8} \mathrm{SiO}_{4}\right]$, but the $\mathrm{Mn}(\mathrm{II})$ minerals consisted 
of kutnohorite, rhodochrosite, and another spectra we could not identify based on our standard suite (Figs. 2, A1, 6). We examined this phase using EBSD but found it was amorphous or too finely grained to generate a diffraction pattern. Textural observations indicated this is a late-stage metamorphic phase, as it had a webbed and fibrous texture and appeared to be growing on and replacing kutnohorite (Figs. 6, A4). By electron probe, we were able to identify that this mineral had a formula of approximately $\mathrm{MnSiO}_{3}$, with $44.8 \% \mathrm{MnO}, 35.6 \% \mathrm{SiO}_{2}, 4.9 \% \mathrm{Al}_{2} \mathrm{O}_{3}, 2.28 \%$ $\mathrm{FeO}, 2 \% \mathrm{MgO}, 0.5 \% \mathrm{Ca}$, and either water or hydroxide groups. This is a good fit for caryopilite, but could be either caryopilite $\left[\mathrm{Mn}(\mathrm{II})_{3} \mathrm{Si}_{2} \mathrm{O}_{5}(\mathrm{OH})_{4}\right]$ or kellyite $\left[(\mathrm{Mn}(\mathrm{II}), \mathrm{Mg}, \mathrm{Al})_{3}(\mathrm{Si}, \mathrm{Al})_{2} \mathrm{O}_{5}(\mathrm{OH})_{4}\right]$, which are both metamorphic manganese silicates. We further examined the mineral using Raman spectroscopy and found the best match was caryopilite (using the online RRUFF database, Fig. A5). Kellyite has a completely different structure and Raman spectrum (Fig. A5).

\subsubsection{South African Hotazel Formation}

The largest known terrestrial manganese deposit occurs in the South African Hotazel Formation - a diverse collection of chemical marine sedimentary rocks that accumulated in either a back-arc setting or a mid-ocean ridge environment (Beukes, 1983; Cornell and Schütte, 1995; Schneiderhan et al., 2006). We performed electron and X-ray analyses of a fresh cut of a mining pit sample (where oxidative weathering has not reached) from the Hotazel Formation. These analyses indicated that the two main minerals previously identified-braunite and kutnohorite (Gutzmer and Beukes, 1996b; Tsikos et al., 2003) — are pervasive, but we observed several other interesting minerals as well. From our SEM imaging of samples from the Hotazel manganese formation, we note multiple generations of manganese-enriched carbonate cements similar to previous observations (Nel et al., 1986; Schneiderhan et al., 2006). These manganese carbonates are approximately kutnohorite $\left[\mathrm{CaMn}\left(\mathrm{CO}_{3}\right)_{2}\right]$ with some $\mathrm{Mg}$ substituting for $\mathrm{Mn}$ : the majority of carbonates bear 35-55 atomic \% $\mathrm{Mn}$ and $30-60 \% \mathrm{Mg}$ with occasionally a small amount of additional $\mathrm{Ca}$ in their second cation. In a few other regions, we observed manganoan calcite with much less $\mathrm{Mg}$ and only about $17-20 \% \mathrm{Mn}$. This phase also seemed to be multigenerational, sometimes appearing highly recrystallized and in other instances appearing to be cross-cut by later kutnohorite (as in Fig. 7, bottom-right image).

The oxide-rich matrix of the Hotazel is dominantly composed of abundant euhedral braunite crystals (appearing white in backscatter imaging) that cross-cut kutnohorite at the scale of the individual crystals (shown in Fig. 7 in image labeled 'matrix'). These observations indicate that some kutnohorite was precipitated earlier than the braunite (Figs. 7, A6). However, it also appears a subsequent generation of kutnohorite grew as nodules into the braunite-kutnohorite matrix, and even later, manganese-bearing carbonate veins cut through the existing material (Figs. 7, A6). These microscale relationships agree with previous observations and hypotheses (Nel et al., 1986; Schneiderhan et al., 2006). Our microscopy also revealed several Mn or Mn-Fe oxide phases that did not appear to contain silicon, but we could not definitively determine the mineralogy of these phases by SEM-EDS.

At the synchrotron, we measured braunite and kutnohorite by XAS on micromilled (bulk) powder from the dark matrix and bright white nodules of the Hotazel, and used X-ray mapping to confirm that braunite and kutnohorite dominate the deposit. However, X-ray mapping also indicated the presence of rare $\mathrm{Mn}(\mathrm{IV})$ oxide minerals that coincided with the silicon-free oxides 
we observed on the SEM. Texturally, these Hotazel Mn(IV) minerals are different from the modern manganese nodule oxides (Fig. 7) (or the surface-weathered samples of Kungarra Formation and Koegas Subgroup discussed in section 3.3) which appear fuzzy and soft. Instead, these Hotazel Mn oxides have a hard, mineralized texture. Several of these Mn(IV) oxides appear to be fibrous and are associated with cross-cutting veins (e.g. spectra 5 in Fig. 7). However, two of the these Mn(IV) oxide minerals are more consistent with early inclusions, or unreacted residues, of original sediment. E-probe measurements of these two oxide types determined that the composition of the fibrous oxides is $\mathrm{Mn}_{0.84} \mathrm{Na}_{0.04} \mathrm{Ca}_{0.03} \mathrm{Fe}_{0.02} \mathrm{O}_{2}$ and one potential early inclusion (shown in bottom-middle of Fig. 7) is $\mathrm{Mn}_{0.85} \mathrm{Na}_{0.05} \mathrm{~K}_{0.04} \mathrm{Fe}_{0.03} \mathrm{Ca}_{0.03} \mathrm{O}_{2}$. The fibrous oxides are likely related to supergene alteration by oxidizing fluids similar to previously observed asbestiform todokorite and manjiroite from the Hotazel Formation (Gutzmer and Beukes, 2000). We examined the two Mn(IV) oxide types, the fibrous and the layered manganese oxides, using electron backscatter diffraction (EBSD) on the SEM and found they were crystalline but poorly matched by standard spectra (Fig. A2). One of the potentially early inclusions is a banded manganese oxide cross-cut by manganoan calcite, kutnohorite, and braunite, suggesting it was present in the sediments earlier than all three of these phases (bottomright image in Fig. 7). Another $\mathrm{Mn}$ and $\mathrm{Fe}$ oxide is also cross-cut by Mn-carbonate cements (Mn(IV)Fe(III) oxide image in Fig. 7). The cross-cutting relationships of these potential inclusions imply that these manganese(IV) oxides are inclusions of the original precipitates in this assemblage.

\subsubsection{South African Koegas Subgroup}

An older manganese-enriched suite of rocks in South Africa is found in the ca. 2.4 Ga Koegas Subgroup, deposited in a deltaic and near-shore marine environment (Schröder et al., 2011; Johnson et al., 2013; Johnson et al., 2014). With a highly manganese-enriched core sample from the Koegas Subgroup (11.6\% MnO in bulk, Johnson et al, 2013), we focused on manganeseenriched carbonate nodules with clear compositional variations to examine the relationships between the different major Mn-bearing carbonate phases in the Koegas samples. While most core samples had micron-scale mixtures of $\mathrm{Ca}-\mathrm{Mn}$ carbonates and Fe-Mn carbonates (Johnson et al., 2013), this sample from core GTF at $230 \mathrm{~m}$ shows discrete zonation of these minerals in carbonate nodules with differential compaction. We measured the two carbonate endmembersshown in SEM photos as bright white-grey (high backscatter) and darker grey (low backscatter) - using the E-probe to measure exact stoichiometry and determined they were composed of a $\mathrm{Mn}_{0.41} \mathrm{Fe}_{0.41} \mathrm{Mg}_{0.14} \mathrm{Ca}_{0.04} \mathrm{CO}_{3}$ (average of white-grey carbonate) and $\mathrm{Ca}_{0.48} \mathrm{Mn}_{0.20} \mathrm{Fe}_{0.18} \mathrm{Mg}_{0.15} \mathrm{CO}_{3}$ (average of dark grey carbonate) using 18 data points from all three nodules (Fig. A7). These minerals are not strictly rhodochrosite nor kutnohorite; they comprise a solid solution between ferroan rhodochrosite, manganoan siderite, and manganoan calcite. All the carbonate phases in this sample appear to have been "ankeritized", with 14 to 15 cation percent magnesium (Fig. A7).

We measured manganese and calcium abundance by XRF at the synchrotron to isolate the 'rhodochrosite-like' and 'kutnohorite-like' endmembers for further measurements. The general trends of $\mathrm{Mn}$ and $\mathrm{Ca}$ concentrations obtained from synchrotron based microprobe observations are consistent with the E-probe measurements and backscatter-highlighted compositional differences. Microprobe XAS spectra through the Ca-rich and Mn-rich portions of the nodule show dramatic changes, with kutnohorite spectra correctly corresponding to the kutnohorite-like 
Ca-rich portions of the nodules and rhodochrosite spectra corresponding to the rhodochrositelike Mn-rich areas (Fig. 8). We were able to accurately image these two carbonate endmembers using the synchrotron XAS microprobe, and this X-ray spectroscopic mapping correctly predicted the mineralogy as observed by differences in SEM backscatter and electron microprobe measurements of the two carbonate present (Figs. 8, A7). With the extent of recrystallization and carbonate diagenesis present in the Koegas strata, it is not possible to conclusively determine whether the manganoan siderite or the manganoan calcite is more primary (Fig. 8).

\subsection{Surface-weathered deposits}

Many manganese deposits are not studied from core or mine samples, but instead from outcrop samples. While we are primarily interested in understanding the Mn mineralogy of diagenetically stabilized deposits and how these phases reflect processes during and after lithification, we also wished to understand how surface weathering changes the redox state and mineralogy of Mn-rich sedimentary rocks. We collected samples from three outcrop sites, two of which we also have studied in drill core or mine exposures to constrain unweathered mineralogy and textures, and we will compare the chemistry of Mn here to our more pristine samples.

From the Santa Cruz Formation manganese deposit, we examined a sample (SD11.08) from a near-surface sample of the fourth manganese stratigraphic layer (position shown in Piacentini et al., 2013). This sample represents a supergene, oxidized example of a similar provenance but different preservation conditions for the Santa Cruz Formation than the thin section sample previously discussed (Fig. 6). The best fit for the spectrum from this sample measured in bulk powder was cryptomelane $\left(\mathrm{KMn}(\mathrm{IV})_{7} \mathrm{Mn}(\mathrm{III}) \mathrm{O}_{16}\right)$, identical to what was obtained from the faultassociated sample (Fig. 6). This mineralization is likely associated with supergene enrichment and oxidative weathering of the more reduced manganese minerals from this deposit (Urban et al., 1992).

We also examined a sample from the 2.415 Ga Koegas Subgroup collected from surface outcrops near Rooinekke, which can be correlated to core samples. The outcrop sample comes from a thin microbialite and grainstone interval in the Rooinekke Formation of the Koegas Subgroup, which has intraformational grains of Mn- and Fe-bearing carbonate (see GTF 63.86m in Fig. 2 of Johnson et al, 2013). High-resolution SEM imaging showed sub-micrometer Mn oxides intermixed with other phases in a replacive texture without a diffraction pattern (Fig. 9). The surface-weathered sample similarly shows discrete, but randomly oriented, Mn-enriched zones, and the XAS measurements are most similar to the Mn(IV) oxides cryptomelane or birnessite (Fig. 9). EDS measurements show peaks of potassium and calcium but no sodiumwhich may be more consistent with Ca-enriched cryptomelane rather than birnessite. Like the Santa Cruz Formation sample, surface weathering again seems to have oxidized $\mathrm{Mn}$ (II) carbonate minerals to $\mathrm{Mn}(\mathrm{IV})$ oxides and destroyed textural information.

A third example of oxidative weathering of manganese-enriched strata was obtained from Australia in the Paleoproterozoic-aged Kungarra Formation. The thin Mn-enriched sedimentary bed has about 7\% $\mathrm{Mn}$ and is constrained to be deposited between ca. $2420 \mathrm{Ma}$ and $2209 \mathrm{Ma}$ (Martin et al., 1998; Takehara et al., 2010; Williford et al., 2011; see SI for more details). Light and electron microscopy of the Kungarra manganese-rich bed show textures similar to the Koegas weathered samples that indicate Mn oxide replacements, and no EBSD pattern could be 
generated as the crystals are likely too small (Figs. 9, A2). X-ray absorption spectroscopy indicates the sample is universally $\mathrm{Mn}(\mathrm{IV})$ oxides, again either fitting birnessite or cryptomelane (Fig. 9). From the potassium and calcium in EDS measurements, this mineral is likely cryptomelane. The massive, fibrous texture of the Mn(IV) oxide shown by SEM (Fig. 9) indicates that the $\mathrm{Mn}(\mathrm{IV})$ is secondary, likely enriched from original Mn-bearing minerals but also possibly introduced by hydrothermal or other fluids as textural relationships have been obscured.

These three examples indicate that while manganese oxidation may be commonly thermodynamically inhibited (Luther, 2010), exposure to oxygen during long intervals integrated by weathering is effective at oxidizing all lower valent minerals to $\mathrm{Mn}(\mathrm{IV})$ oxide phases, by processes that also alter the primary textures.

\section{DISCUSSION}

While $\mathrm{Mn}(\mathrm{IV})$ oxides appear to be the primary Mn phase entering sediments, we consistently observe that $\mathrm{Mn}$ is converted to other phases by diagenetic (secondary) processes. Surprisingly, this diversity of $\mathrm{Mn}$ deposits displays relatively few predominant minerals, suggesting the operation of common and widespread diagenetic processes in Mn-rich sediments over much of Earth history. From our survey of the mineralogy, textures and chemistry of manganese deposits, we can divide our observations into three categories: 1) manganese deposits composed of essentially all Mn(IV) oxides, such as the modern seafloor manganese nodules or surfaceweathered manganese deposits, 2) deposits where the $\mathrm{Mn}$ is found exclusively in $\mathrm{Mn}$ (II) carbonates, such as the Koegas deposit, the Molango deposit, and the Miocene Japan Sea Mnrich sediments, and 3) deposits with subequal mixtures of $\mathrm{Mn}(\mathrm{II})$ - and $\mathrm{Mn}$ (III)-bearing minerals like in the manganese-rich intervals in the Hotazel Formation and the Santa Cruz Formation.

In marine and lacustrine sediments manganese oxidation processes form Mn(IV)-dominated oxides like birnessite (Fig. 3; Tebo et al., 2004) and the reduction of these oxides produces Mnbearing carbonates (Thamdrup et al., 1993; Calvert and Pedersen, 1996; Fischer et al., 2008; Ying et al., 2011; Lee et al., 2011). Mn oxidation may yield a Mn(III) intermediate that is observable as a short-lived (and potentially important) redox player in suboxic environments (Madison et al., 2013). However, it is not common to observe substantial accumulation of $\mathrm{Mn}(\mathrm{III})$ species because they typically disproportionate into $\mathrm{Mn}^{2+}$ and $\mathrm{Mn}(\mathrm{IV})$ oxides or are subsequently fully oxidized to Mn(IV) oxides that are added to the sediments (Perez and Jeffries, 1992; Wariishi et al., 1992; Webb et al., 2005; Anderson et al., 2009; Learman et al., 2011; Hansel et al., 2012). Reduction of Mn(IV) oxides also may proceed through a short-lived Mn(III) intermediate (Lin et al., 2012), but again, the final product of manganese reduction is $\mathrm{Mn}^{2+}$ (Lovley and Phillips, 1988; Myers and Nealson, 1988; Aller, 1990; Van Cappellen et al., 1998; Thamdrup et al., 2000). Thus the widespread observation of non-transient but stable and abundant Mn(III) phases in the rock record, as documented by this study and others (Gutzmer and Beukes, 1996b; Tsikos et al., 2003; Roy, 2006; Maynard, 2010), is intriguing and requires explanation.

Indeed, all the manganese from well-preserved samples of ancient deposits, whether 3 million years old or 2.2 billion years old, are more reduced than the modern Mn-rich surface sediments (with the notable exception of rare $\mathrm{MnO}_{2}$ inclusions in some early-diagenetic Hotazel 
kutnohorite nodules). These observations illustrate that there are common and effective postdepositional reduction processes that convert the $\mathrm{Mn}(\mathrm{IV})$ precipitates in sediments to $\mathrm{Mn}$ (II) and $\mathrm{Mn}$ (III) minerals (that remain stable for billions of years) during early and late diagenesis. Using micro-scale observations of mineralogy and chemistry tied to petrographic textures, we can ordinate these different phases and develop a general framework for how post-depositional processes impact manganese mineralogy and redox state and determine a paragenetic sequence of manganese minerals.

\subsection{Paragenetic model}

The first precipitates to enter and concentrate $\mathrm{Mn}$ in sediments are $\mathrm{Mn}(\mathrm{IV})$-dominated oxides. The deep-sea manganese nodule from the seafloor being fully comprised of $\mathrm{Mn}(\mathrm{IV})$-dominated oxides lends support to this, as well as many reports of Mn(IV) oxides being the dominant precipitate produced by manganese oxidation (e.g., Tebo et al., 2004). The discovery of microscale Mn(IV) oxide inclusions in early diagenetic carbonate nodules, which we propose is a primary residue from the original sedimentary precipitates on the basis of petrographic textures, is an additional line of evidence suggesting these manganese deposits began as sediment rich in Mn(IV)-dominated oxides. The weathered samples of Mn-bearing rocks confirms that when oxygen is present for a sufficient amount of time, manganese seems to be oxidized and stabilized as Mn(IV)-oxide phases.

The precipitation of $\mathrm{Mn}$ (II)-bearing carbonates from the reduction of $\mathrm{Mn}(\mathrm{IV})$ oxides by organic carbon has been inferred previously from observations of the geologic record (Okita et al., 1988; Polgári et al., 1991; Tsikos et al., 2003). Often, the diagenetic reaction is presented as below:

$2 \mathrm{Mn}(\mathrm{IV}) \mathrm{O}_{2}+\mathrm{CH}_{2} \mathrm{O}+4 \mathrm{H}^{+} \rightleftharpoons 2 \mathrm{Mn}^{2+}+\mathrm{CO}_{2}+3 \mathrm{H}_{2} \mathrm{O}$

$\mathrm{Mn}^{2+}+\mathrm{CO}_{3}^{2-} \rightleftharpoons \mathrm{MnCO}_{3}$

implying rhodochrosite, or $\mathrm{MnCO}_{3}$, is the reaction product promoted by the inorganic carbon, alkalinity and $\mathrm{Mn}^{2+}$ production in Reaction (1). However, we document in many units (for e.g., the Koegas, Molango, Urucum and Hotazel deposits) the abundance of kutnohorite-like minerals (similar to $\mathrm{Mn}_{0.5} \mathrm{Ca}_{0.5} \mathrm{CO}_{3}$ ). This mixed $\mathrm{Ca}-\mathrm{Mn}$ carbonate precipitation is also promoted from similar Mn(IV) reduction reactions described in Reaction (1) if the precipitating carbonate in Reaction (2) incorporates $\mathrm{Ca}$ that is abundant in pore fluids. These manganese reduction reactions commonly occur by interaction between dissimilatory metal-reducing microbes and solid Mn(IV) oxides in the absence of oxygen (Lovley and Phillips, 1988; Myers and Nealson, 1988; Aller, 1990; Van Cappellen et al., 1998). While manganese reduction does take place in anoxic waters, such as the Black Sea, the Mn(II) produced is diluted into the surrounding water column, and does not sufficiently increase in concentration to form Mn-carbonates (Calvert and Pederson, 1996). Thus, the production of Mn-carbonates post-Mn(IV) reduction likely only takes place in porewater-filled cavities of anoxic sediments enriched in "trapped" manganese oxides (Calvert and Pedersen, 1996). Marine sedimentary porewater is Ca-rich at $\sim 10.5 \mathrm{mM}$ (Wenzhöfer et al., 2001; Rao et al., 2012), and increasing the $\mathrm{Mn}^{2+}$ concentration of seawater promotes the precipitation of carbonates with kutnohorite-like composition. Bottcher (1998) precipitated calcium-manganese carbonates at 20,60 , and $90^{\circ} \mathrm{C}$, and the carbonate precipitates had a manganese composition that was enriched but related to the $\mathrm{Ca}: \mathrm{Mn}$ concentrations. 
Similarly, Mucci (2004) synthesized a calcian rhodochrosite by combining equal molar solutions of $\mathrm{Ca}$ and $\mathrm{Mn}$. He demonstrated that either manganoan calcite or calcian rhodochrosite will form depending on the porewater $\mathrm{Mn}: \mathrm{Ca}$ concentrations, calcite surfaces, and reaction kinetics (Mucci, 2004). Thus in the presence of high porewater Ca levels (i.e. seawater compositions), manganese oxide reduction would promote the precipitation of carbonates with roughly equal amounts of $\mathrm{Mn}$ and $\mathrm{Ca}$, as opposed to endmember carbonates like rhodochrosite $\left(\mathrm{MnCO}_{3}\right)$.

In the environment, Mn-bearing carbonates from a variety of unlithified sediments are invariably mixed $\mathrm{Mn}-\mathrm{Ca}(+/-\mathrm{Mg})$ carbonates rather than endmember rhodochrosite, including sediments in the Baltic Sea, Panama Basin, Loch Fyne, among other locations (Calvert and Price, 1970; Pedersen and Price, 1982; Jakobsen and Postma, 1989; Calvert and Pedersen, 1996; Neumann et al., 2002). For example, Baltic Sea sediments have reported to contain calcian rhodochrosite with about $70-75 \% \mathrm{Mn}$ and $25-30 \% \mathrm{Ca}$ that precipitated in essentially modern organic-rich marine muds (Neumann et al., 2002). Modeling the precipitation dynamics similarly results in formation of kutnohorite or calcic-rhodochrosites depending on Mn concentration, and pure rhodochrosite is not a stable phase in reasonable porewater compositions (Middelburg et al., 1987).

Since all of our examined sedimentary deposits are marine in origin, and it is unlikely that $\mathrm{Ca}$ levels in the oceans have changed substantially since Archean time (Grotzinger and Kasting, 1993; Lowenstein et al., 2001; Fischer et al., 2009), the early diagenetic carbonate precipitate of all of these deposits was likely kutnohorite or a calcian rhodochrosite. This notion is supported by our textural observations of the different Mn-bearing carbonate cements in these units. Further support for a kutnohorite or calcian rhodochrosite forming earlier in the diagenetic sequence comes from other Mn deposits: for example, calcium-rich manganese carbonates have also been found in Úrkút, Hungary (Polgári et al., 2007), a Jurassic deposit with a low thermal history implied by its relatively unaltered oxygen isotopes (Polgári et al., 1991; Hein et al., 1999). Pure rhodochrosite, then, either forms in Ca-depleted porewaters (which seems unlikely) or more probably as a secondary carbonate associated with dissolution and higher-temperature re-precipitation of carbonate closer to endmember $\mathrm{MnCO}_{3}$. Carbonate mineral textures from light and electron microscopy (e.g., Figs. 4,5) demonstrate substantial amounts of carbonate diagenesis - recrystallization and precipitation of secondary and tertiary cements that are commonly chemically zoned. It is also interesting, and perhaps illuminating, that the $\mathrm{Mn}(\mathrm{IV})$ oxide inclusion in the Hotazel formation occurs occluded by kutnohorite nodular cements, not rhodochrosite, also implying that kutnohorite may be an earlier diagenetic precipitate rather than rhodochrosite (Fig. 7).

Textural observations of the Mn(III)-rich phase braunite from the Hotazel and Santa Cruz formations indicate that it formed after kutnohorite, but unlike previous suggestions (Maynard, 2010), the braunite still appears as though it formed early in diagenesis as the braunite is generally fine-grained and defines sedimentary lamination. Yet the timing and formation process of braunite during diagenesis and/or metamorphism is unclear (Robie et al., 1995). The composition of braunite is related to the manganese(III) oxide bixbyite $\left(\mathrm{Mn}(\mathrm{III})_{2} \mathrm{O}_{3}\right)$, but with substitution of $\mathrm{Mn}^{2+}$ and $\mathrm{Si}^{4+}$ for $2 \mathrm{Mn}^{3+}$. Interestingly, the $\mathrm{Si}$ content of braunite appears to be relatively invariable with metamorphic grade (Abs-Wurmbach, 1980). Braunite has not been synthesized in the laboratory, but there are several proposed mechanisms for its formation (Robie 
et al., 1995); we highlight those with plausible initial conditions for marine sediments (e.g., rhodonite, a high-temperature metamorphic $\mathrm{Mn}$ (II) silicate is not a likely precursor precipitate):

$14 \mathrm{Mn}_{2} \mathrm{O}_{3}($ Bixbyite $)+4 \mathrm{SiO}_{2}($ Silica $) \rightleftharpoons 4 \mathrm{Mn}(\mathrm{III})_{6} \mathrm{Mn}(\mathrm{II}) \mathrm{SiO}_{12}($ Braunite $)+\mathrm{O}_{2}$

$7 \mathrm{Mn}_{3} \mathrm{O}_{4}$ (Hausmannite) $+3 \mathrm{SiO}_{2}+\mathrm{O}_{2} \rightleftharpoons 3 \mathrm{Mn}_{7} \mathrm{SiO}_{12}$

$14 \mathrm{MnCO}_{3}$ (Rhodochrosite) $+2 \mathrm{SiO}_{2}+3 \mathrm{O}_{2} \rightleftharpoons 2 \mathrm{Mn}_{7} \mathrm{SiO}_{12}+14 \mathrm{CO}_{2}$

We favor Reaction (1) as the most plausible mechanism for braunite formation. While we do not observe bixbyite or hausmannite, either or both of these minerals may well have been present in porewater during diagenesis. However, both Reaction (II) beginning with hausmannite and Reaction (III) beginning with rhodochrosite require oxygen in the sediments to form braunite. When we have observed evidence of oxidizing fluids moving through discrete veins or faults, we see $\mathrm{Mn}(\mathrm{IV})$ oxides in the Hotazel and Urucum examples, not braunite enrichments. It is also difficult to envision the correct amount of oxygen being introduced post-depositionally into the whole of the Hotazel deposit to produce braunite throughout the entire formation. Thus we prefer a mechanism similar to Reaction (I), which seems the simplest explanation for a silicified Mn(III)-dominated mineral: begin with a Mn(III) oxide and add silica. We would expect this silica to be aqueous $\left(\mathrm{H}_{4} \mathrm{SiO}_{4}\right)$ in diagenetic or hydrothermal fluids, and this reaction may need to occur in a $\mathrm{Mn}^{2+}$-rich solution to promote the $\mathrm{Si}^{4+}$ and $\mathrm{Mn}^{2+}$ substitution. The subsequent 'hydrous braunite' formed may have been later crystallized into euhedral braunite during early metamorphism. With its importance in Earth's largest manganese deposits, further laboratory experiments and mineralogical exploration are required to test these hypotheses and further our understanding of braunite formation.

Our observations primarily constrain the timing of braunite formation. The euhedral braunite crystals in the Hotazel Formation cross-cut kutnohorite and are therefore definitively younger (Figs. 7, A6). However, if manganese reduction converts $\mathrm{Mn}(\mathrm{IV})$-oxides to $\mathrm{Mn}^{2+}$, for $\mathrm{Mn}(\mathrm{III})$ production we either need secondary oxidation of the $\mathrm{Mn}^{2+}$, or some way to produce $\mathrm{Mn}$ (III) oxides from either Mn(IV) oxides or Mn(II) carbonates, to eventually crystallize into braunite. Experimental evidence has suggested that $\mathrm{Mn}(\mathrm{IV})$-oxide reduction by the metal-reducing bacteria of the genus Shewanella may proceed through a Mn(III) step, which could be a Mn(III) oxide source (Lin et al., 2012). The difficulty here is to keep this Mn(III) from becoming fullyreduced $\mathrm{Mn}^{2+}$, but this could occur via more stable $\mathrm{Mn}$ (III)-ligand complexes (Madison et al., 2013) or the formation of Mn(III) oxyhydroxides, which can be temporarily stable (Hem and Lind, 1983; Murray et al., 1985). Another possibility is the synthesis of Mn(III)-oxyhydroxides like feitknechtite $(\beta-\mathrm{MnOOH})$ from abiotic reaction of co-existing $\mathrm{Mn}^{2+}$ and $\mathrm{Mn}(\mathrm{IV})$ oxides in porewater (Bargar et al., 2005; Elzinga, 2011), as shown below:

$\mathrm{Mn}(\mathrm{IV}) \mathrm{O}_{2}+\mathrm{Mn}^{2+}+2 \mathrm{H}_{2} \mathrm{O} \rightleftharpoons 2 \mathrm{MnOOH}+2 \mathrm{H}^{+}$

While any of these options to form $\mathrm{MnOOH}$ are possible, we do know that some Mn(III)dominated phase must have existed in the Hotazel and Santa Cruz sediments, and after the precipitation of $\mathrm{Mn}(\mathrm{II})$-carbonate, this $\mathrm{Mn}(\mathrm{III})$ phase was ultimately stabilized as brauniteperhaps with diagenetic addition of silica. 
The Santa Cruz Formation also contains caryopilite - the Mn(II) aluminosilicate member of the kaolinite-serpentine group. This mineral appears to have formed during burial diagenesis or metamorphism from late-stage alteration and silicification of kutnohorite into caryopilite. Crosscutting relationships show caryopilite is secondary to the Mn-carbonate, and caryopilite is a known metamorphic mineral (Brusnitsyn, 2006); thus we regard these Mn-silicates as the result of much later post-depositional processes.

Combining knowledge of Mn redox dynamics, reduction processes, and our observations of texture, mineralogy, and redox dynamics, we can construct a conceptual model of manganese precipitation, diagenesis, and stabilization in the geological record (Fig. 10). Mn(IV)-oxides constitute the principal mode by which Mn enters and is concentrated in marine sediments, but these are subsequently reduced either completely or partially by sedimentary organic matter and/or related reductants (e.g. sulfide). Reduction by organic matter is commonly mediated by anaerobic microbes and promotes the precipitation of $\mathrm{Mn}$-carbonates, forming first $\mathrm{Ca}$-rich phases like kutnohorite and calcian rhodochrosite, but which often undergo carbonate diagenesis to produce endmember rhodochrosite. During reduction of $\mathrm{Mn}(\mathrm{IV})$ oxides, $\mathrm{Mn}$ (III) oxides or complexes are produced, which later are crystallized in the presence of silica to the $\mathrm{Mn}$ (III)dominated oxide, braunite.

Our observations display a general pattern of manganese deposits composed either exclusively of $\mathrm{Mn}(\mathrm{II})$ carbonates or a mixture of $\mathrm{Mn}$ (III) and $\mathrm{Mn}$ (II) phases, but what determines which of these two assemblages occur? We have established that $\mathrm{Mn}$ (II) carbonates derive from $\mathrm{Mn}(\mathrm{IV}$ ) oxides through reduction by organic carbon, and the $\mathrm{Mn}(\mathrm{III})$ precursor phase to braunite may form via partial reduction of $\mathrm{Mn}(\mathrm{IV})$ oxides or by $\mathrm{Mn}(\mathrm{IV})$ oxides reacting with $\mathrm{Mn}$ (II). We hypothesize that the kinetics of $\mathrm{Mn}$ (IV) reduction is critical to determining whether $\mathrm{Mn}$ (III) phases form since the stabilization of $\mathrm{Mn}$ (III)-oxides requires the presence of $\mathrm{Mn}(\mathrm{IV})$ and Mn(II). However, Mn(III) can still be reduced by metal-reducing microbes (Kostka et al., 1995), and so ultimately the assemblage redox state must be determined by the relative flux of reductant. If organic carbon, or other reduced chemical species able to reduce Mn(IV) oxides, fluxes to the sediment are greater than that of manganese, then all the Mn oxides should be reduced to $\mathrm{Mn}$ (II) and react to form $\mathrm{Mn}$ (II) carbonates or diffuse away. If organic carbon or other reductants are limiting, then the surplus of manganese should result in more oxidized phases being preserved. Theoretically, this should mean that with little organic carbon input, there is potential for preserving original manganese oxides - and while this may have happened in rare instances in marine sedimentary basins (exemplified by the Mn-rich facies in the Hotazel Formation and Santa Cruz Formation), it is clear that usually manganese is more commonly reduced by available electron donors. This premise of competing manganese-electron donor dynamics allows one to infer the relative organic carbon availability in ancient paleoenvironments: for example, in the Molango shallow sea, relative sedimentary organic carbon fluxes were high, but in the Urucum continental rift basin they were not.

Later metamorphic processes may transform the kutnohorite, rhodochrosite and/or braunite into a variety of other minerals, such as the Mn(II) aluminosilicate caryopilite observed in the Santa Cruz Formation. Diagenetically-stabilized Mn deposits may again be exposed to oxygen via uplift and surface weathering, and all the minerals will once again be fully oxidized to Mn(IV) 
oxides as in the Koegas, Urucum and Kungarra formation examples. This will occur from abiotic weathering in the presence of $\mathrm{O}_{2}$ (Morgan, 2005), but recent reports suggest the oxidation of $\mathrm{Mn}$ carbonates to Mn(IV) oxides may also be microbially mediated (Tang et al., 2013). Thus to achieve an accurate understanding of early Mn mineralization both unweathered core samples and texture-specific measurements are essential to determine how $\mathrm{Mn}$ was delivered to the sediments and how it was transformed by diagenesis.

\section{CONCLUSIONS}

We combined light and electron microscopy, X-ray absorption spectroscopy and X-ray imaging techniques to examine key manganese deposits through time and understand their mineralogy and petrogenesis in detail across multiple scales. While manganese oxidation produces Mn(IV)dominated oxides and comprises the major vector for the sedimentation and concentration of Mn in sedimentary rocks, ancient manganese deposits are composed only of $\mathrm{Mn}$ (II) and $\mathrm{Mn}$ (III) minerals (with rare exceptions of small preserved Mn(IV)-oxide inclusions). The geological record of (relatively) well-preserved manganese deposits is thus composed predominantly of kutnohorite-like minerals (variants of $\left.\mathrm{Mn}_{0.5} \mathrm{Ca}_{0.5} \mathrm{CO}_{3}\right)$, rhodochrosite $\left(\mathrm{MnCO}_{3}\right)$ and braunite $\left(\mathrm{Mn}(\mathrm{III})_{6} \mathrm{Mn}(\mathrm{II}) \mathrm{O}_{8} \mathrm{SiO}_{4}\right)$. A dataset of the abundances of $\mathrm{Mn}$ deposits throughout Earth history reveals fundamental secular changes, with Mn deposition only emerging after the rise of oxygen; a notable exception is found in the Paleoproterozoic-age Koegas subgroup of the Transvaal Supergroup, deposited just prior to the rise of oxygen. Constrained by texture-specific mineral analyses and sedimentological observations, we constructed a paragenetic model of manganese mineral formation beginning with deposition of $\mathrm{Mn}$ (IV)-dominated oxides leading to the early diagenetic production of carbonate phases such as kutnohorite and calcian rhodochrosite, with potential for stabilization of $\mathrm{Mn}$ (III)-rich oxides (now marked by braunite) in sedimentary environments with relatively low fluxes of sedimentary organic matter. Deeper burial promotes the ingrowth of a metamorphic mineral assemblage (recrystallization of carbonate phases and production of $\mathrm{Mn}$ (II)-silicates), and finally there can be re-oxidation to $\mathrm{Mn}(\mathrm{IV})$-oxides driven by post-depositional exposure to $\mathrm{O}_{2}$-bearing fluids during near-surface weathering. This framework provides logic to invert sedimentological, mineralogical, and textural observations of Mn-rich sedimentary rocks for the biogeochemical processes operating on ancient Earth's surface environments.

\section{ACKNOWLEDGEMENTS}

We are grateful for manuscript comments and analytical support from George Rossman, Alex Sessions, and Victoria Orphan, and the careful feedback provided by five anonymous reviewers. We thank the David and Lucile Packard Foundation and a NSF-GRFP Grant No. DGE-1144469 to J.E.J. for support. We acknowledge the Lewis and Clark Foundation for funding field work for J.E.J., the Agouron Institute for supporting both the Agouron South Africa Drilling Project which provided core samples of the Koegas Subgroup and the Agouron Field Excursions that allowed J.E.J. to sample the Kungarra Formation, Victoria Orphan and Benjamin Harris for donating part of a deep-sea ferromanganese nodule, J.B. Maynard for contributing many Molango deposit samples, Joseph Kirschvink for donating a well-preserved sample of the Hotazel Formation, Thiago Piacentini for samples of the Santa Cruz Formation, and Nic Beukes and Bertus Smith for assistance in the field. The Stanford Synchrotron Radiation Lightsource, SLAC National Accelerator Laboratory, is supported by the U.S. Department of Energy, Office of Science, Office of Basic Energy Sciences under Contract No. DE-AC02-76SF00515. SEM, 
EBSD and EPMA analyses were carried out at the Caltech GPS Division Analytical Facility, which is supported, in part, by NSF Grants EAR-0318518 and DMR-0080065.

\section{FIGURE CAPTIONS}

Fig. 1: Manganese ore deposits through time

Estimated volumes of major sedimentary manganese deposits plotted as a function of their bestconstrained geologic age. Arrows mark deposits analyzed in this study, with black signifying large manganese deposits plotted and grey indicating timing of smaller deposits. Supergene deposits are shown in grey for cases where the age of mineralization is known; deposits from Archean proto-ore, primarily in India, occur but the age of mineralization is not known. References: (Maxwell, 1972; Varentsov and Grasselly, 1976; Varentsov and Grasselly, 1976; National Materials Advisory Board, 1981; Taljaardt, 1982; Martino, 1986; Dasgupta et al., 1991; Pracejus and Bolton, 1992; Urban et al., 1992; Davis et al., 1994; Babinski et al., 1995; Gutzmer and Beukes, 1996b; Fan and Yang, 1999; Rodionov et al., 2004; Cairncross and Beukes, 2013; Cairncross and Beukes, 2013; Jones et al., 2013)

Fig. 2: Mn K-edge X-ray absorption spectra of relevant manganese minerals Manganese mineral standards to compare to sample measurements. Standards obtained from the Caltech Mineralogical Collection or acquired by the Fischer lab.

Fig. 3: Microscopy and X-ray analyses of a seafloor manganese nodule Photographs and analyses of a section through a ferromanganese nodule from the South Pacific Gyre collected during Expedition Knox-02RR. Leftmost panel shows photographs of the entire nodule (above) and thin section (below). Center panels show Mn concentration map ranging from 0 to $1726 \mu \mathrm{g} / \mathrm{cm}^{2}$ (jet colors) and a best-fit Mn redox map where $\mathrm{Mn}$ (II) is fitted in blue, $\mathrm{Mn}(\mathrm{III})$ in red, and $\mathrm{Mn}(\mathrm{IV})$ in green. Only $\mathrm{Mn}(\mathrm{IV})$ was found to be present by X-ray spectroscopic mapping. Top right panels contain electron photomicrographs of the nodule at different scales; note the abundant isopachous and stromatolitic laminations. Bottom right shows XAS spectra through the Mn edge of various points throughout the nodule and a bulk sample. All spectra are Mn(IV) oxides best matched by birnessite, supporting the redox map.

Fig. 4: Microscopy and X-ray analyses of Miocene sediments from Japan Sea

Transmitted light (top left) photos of a manganese-enriched sample at $533 \mathrm{~m}$ from ODP core 799 from the Japan Sea. Representative regions were mapped for Mn concentration (jet colors) and $\mathrm{Mn}$ redox state ( $\mathrm{Mn}(\mathrm{II})$ in blue, $\mathrm{Mn}(\mathrm{III})$ in red, $\mathrm{Mn}(\mathrm{IV})$ in green) (top right). While $\mathrm{Mn}$ concentration is variable, the manganese redox state is all $\mathrm{Mn}$ (II). Bottom left panel shows carbonate speciation maps of same region, with rhodochrosite $\left[\mathrm{MnCO}_{3}\right]$ in pink and kutnohorite $\left[\mathrm{MnCa}\left(\mathrm{CO}_{3}\right)_{2}\right]$ in green. SEM images of subregions shown on right with identifications made using EDS. Note consistency between SEM-identified mixed $\mathrm{Ca}, \mathrm{Mn}$ carbonates and purer rhodochrosite (identified with $\mathrm{Mn}(\mathrm{Ca}) \mathrm{CO}_{3}$ ) and the X-ray maps. Spectra (shown on bottom right) taken on target points confirm mineralogy. Also included are spectra of bulk powder at $533 \mathrm{~m}$ and three other bulk powders from $196 \mathrm{~m}, 326 \mathrm{~m}$, and $502 \mathrm{~m}$. Other than $326 \mathrm{~m}$ which has very little $\mathrm{Mn}$, the bulk powders show $\mathrm{Mn}(\mathrm{II})$ in carbonates.

Fig. 5: Jurassic-age Molango deposit microscopy and X-ray analyses 
Analyses of a rock sample from the Aco section at $2.4 \mathrm{~m}$ (Okita and Shanks, 1992); two other examples can be found in Fig. A3. Transmitted light photo of representative region (top left) and Mn concentration maps (top center, jet colors in cps units). Below shows redox map (Mn(II) in blue, $\mathrm{Mn}(\mathrm{III})$ in red, and $\mathrm{Mn}(\mathrm{IV})$ in green) of region indicating all $\mathrm{Mn}$ is $\mathrm{Mn}(\mathrm{II})$, and a carbonate speciation map showing most of the $\mathrm{Mn}$ in this section is hosted by rhodochrosite. Spectra on top right confirm the $\mathrm{Mn}$ is in Mn carbonates, both from bulk and point spectra. Bottom panel shows SEM photos of subregions from the same section. Abundant rhodochrosite can be found, but the majority of it appears as rims (bright white in backscatter photos). Other mixed carbonates with more Ca appear as slightly darker white or grey and may be more primary precipitates.

Fig. 6: Neoproterozoic Santa Cruz Formation microscopy and X-ray analyses

Transmitted light (top left) photo of Santa Cruz Formation thin section from the Urucum mine. Also on right are two representative SEM photos of the section: note Mn silicate fibers growing on mixed CaMn carbonate and bright white crystals of braunite. Minerals identified tentatively by EDS and confirmed using Raman, EBSD and XAS. Same region was mapped for Mn concentration (jet colors, in $\mu \mathrm{g} / \mathrm{cm}^{2}$ from 0 to 1071), and for Mn redox, with both $\mathrm{Mn}$ (II) (blue) and $\mathrm{Mn}(\mathrm{III})$ (red) (no $\mathrm{Mn}(\mathrm{IV})$ was found). Rightmost map is map of Mn speciation mapping braunite (red), Mn carbonate (blue) and Mn silicate (green). Note co-localization of Mn carbonate and Mn silicate (identified as caryopilite by Raman, see Fig. A5). Right panel shows spectra from four representative points through the section indicating the $4 \mathrm{Mn}$-bearing minerals present, and two bulk powder measurements of a fault-associated sample and a weathered sample. Standards shown above to compare.

Fig. 7: Paleoproterozoic Hotazel Formation microscopy and X-ray analyses

Transmitted light (top left) images of a sample from the Hotazel Formation of the Paleoproterozoic Kalahari Manganese Field from South Africa. Large Mn concentration map shown below, in jet colors ranging from 0 to $2745 \mu \mathrm{g} / \mathrm{cm}^{2}$. Three representative areas $(1,2,3)$ are highlighted with Mn concentration maps (jet colors in cps), Mn redox maps (Mn(II) in blue, $\mathrm{Mn}(\mathrm{III})$ in red, $\mathrm{Mn}(\mathrm{IV})$ in green). The Mn-carbonate nodules appear to float in a Mn(III)-oxide matrix, with rare Mn(IV) oxides. A representative matrix SEM photo shows braunite crosscutting a background of kutnohorite, and other SEM photos labeled with numbers with subregions of $\mathrm{Mn}(\mathrm{IV})$ oxides. Representative spectra shown on right and confirm X-ray spectroscopic mapping.

Fig. 8: Paleoproterozoic Koegas Subgroup microscopy and X-ray analyses A representative manganese-enriched nodule from the $\sim 2.4$ Ga Koegas Subgroup in South Africa (more are shown in Fig. A7). Nodule was mapped for Mn concentration and Ca concentration (jet colors, in cps) and a redox map produced, shown on top right. Mn is all $\mathrm{Mn}$ (II), shown in blue. Below, nodule was photographed in electron backscatter and X-ray spectroscopic mapping was used to produce a carbonate speciation map, where rhodochrosite $\left[\mathrm{MnCO}_{3}\right]$ is fit in pink and kutnohorite $\left[\mathrm{MnCa}\left(\mathrm{CO}_{3}\right)_{2}\right]$ is fit in green. The area of each carbonate mineral is very discrete and matches the dramatic backscatter differences of the nodule core and rim. X-ray spectra through the nodule confirm speciation maps, showing a rhodochrosite spectrum in rim and kutnohorite in nodule core. Bottom left image is an SEM image of what appears to be a mixed CaFeMn carbonate being replaced by a backscatter-brighter FeMn carbonate. 
Fig. 9: Oxidatively weathered outcrop samples: Koegas Subgroup and Kungarra Formation

Top left shows weathered outcrop sample in transmitted light from a microbially-bound grainstone in the Koegas Subgroup, South Africa. Small Mn concentration maps (jet colors, in cps) and $\mathrm{Mn}$ redox maps (Mn(II) in blue, $\mathrm{Mn}(\mathrm{III})$ in red, $\mathrm{Mn}(\mathrm{IV})$ in green) shown adjacent on right. All Mn appears to be Mn(IV). SEM photos below indicate Mn oxides are fine-grained masses that mask petrographic textures. Mn(IV) oxides are high in $\mathrm{Ca}$ and $\mathrm{K}$, and spectra (top right) suggest this may be cryptomelane (a K-bearing Mn(IV) oxide) or possibly birnessite. Bottom panel shows a former nodule from the Kungarra Formation, Australia, from an oucrop sample that was highly weathered. Manganese concentration map (jet colors in cps units) shows manganese enriched in the nodule and a Mn redox map (Mn(II) fitted in blue, $\mathrm{Mn}$ (III) in red, $\mathrm{Mn}(\mathrm{IV})$ in green) indicates all Mn is Mn(IV) oxides. Like the Koegas Subgroup sample, spectra best match cryptomelane or birnessite.

Fig. 10: Paragenetic model for the diagenetic stabilization of Mn deposits

Manganese is introduced to the sediments as $\mathrm{Mn}(\mathrm{IV})$ oxides, but then these Mn concentrates are subsequently reduced during diagenesis either partially to $\mathrm{Mn}(\mathrm{III})$ phases or fully to $\mathrm{Mn}^{2+}$. Often this reduction is microbially-mediated using organic compounds. $\mathrm{Mn}^{2+}$ is then precipitated as Mn-bearing carbonates, while $\mathrm{Mn}(\mathrm{III})$-oxide phases are silicified and stabilized as braunite $\left(\mathrm{Mn}(\mathrm{III})_{6} \mathrm{Mn}(\mathrm{II}) \mathrm{SiO}_{12}\right)$. The most primary of these appears to be manganese-calcium carbonates like kutnohorite or calcic rhodochrosite but with burial diagenesis, these can undergo recrystallization and yield more manganese-enriched carbonate phases like pure rhodochrosite $\left(\mathrm{MnCO}_{3}\right)$. Increasing burial diagenesis and metamorphism can greatly increase the mineralogical diversity of Mn deposits, particularly with Mn-silicate minerals, including caryopilite. See text for details.

\section{REFERENCES}

Abs-Wurmbach I. (1980) Miscibility and compatibility of braunite, Mn2+Mn 6 3+ O8/SiO4, in the system Mn-Si-O at 1 atm in air. Contrib. Mineral. Petrol. 71, 393-399.

Aller R. C. (1990) Bioturbation and Manganese Cycling in Hemipelagic Sediments. Philos. Trans. R. Soc. Lond. Ser. Math. Phys. Sci. 331, 51-68.

Anbar A. D. and Holland H. D. (1992) The photochemistry of manganese and the origin of banded iron formations. Geochim. Cosmochim. Acta 56, 2595-2603.

Anderson C. R., Johnson H. A., Caputo N., Davis R. E., Torpey J. W. and Tebo B. M. (2009) $\mathrm{Mn}(\mathrm{II})$ oxidation is catalyzed by heme peroxidases in "Aurantimonas manganoxydans" strain SI85-9A1 and Erythrobacter sp. strain SD-21. Appl. Environ. Microbiol. 75, 41304138.

Armstrong F. A. (2008) Why Did Nature Choose Manganese to Make Oxygen? Philos. Trans. $R$. Soc. B Biol. Sci. 363, 1263-1270.

Babinski M., Chemale Jr. F. and Van Schmus W. R. (1995) The Pb/Pb age of the Minas Supergroup carbonate rocks, Quadrilátero Ferrífero, Brazil. Precambrian Res. 72, 235245. 
Bargar J. R., Tebo B. M., Bergmann U., Webb S. M., Glatzel P., Chiu V. Q. and Villalobos M. (2005) Biotic and abiotic products of $\mathrm{Mn}(\mathrm{II})$ oxidation by spores of the marine Bacillus sp. strain SG-1. Am. Mineral. 90, 143-154.

Bargar J. R., Tebo B. M. and Villinski J. E. (2000) In situ characterization of Mn(II) oxidation by spores of the marine Bacillus sp. strain SG-1. Geochim. Cosmochim. Acta 64, 27752778.

Bekker A., Holland H. D., Wang P.-L., Rumble D., Stein H. J., Hannah J. L., Coetzee L. L. and Beukes N. J. (2004) Dating the rise of atmospheric oxygen. Nature 427, 117-120.

Beukes N. J. (1987) Facies relations, depositional environments and diagenesis in a major early Proterozoic stromatolitic carbonate platform to basinal sequence, Campbellrand Subgroup, Transvaal Supergroup, Southern Africa. Sediment. Geol. 54, 1-46.

Beukes N. J. (1983) Palaeoenvironmental Setting of Iron-Formations in the Depositional Basin of the Transvaal Supergroup, South Africa. In Developments in Precambrian Geology (eds. A. F. Trendall and R. C. Morris). Elsevier, Amsterdam, The Netherlands. pp. 131198. Available at: http://www.sciencedirect.com/science/article/pii/S0166263508700434 [Accessed March 22, 2013].

Brand U. and Veizer J. (1980) Chemical diagenesis of a multicomponent carbonate system; 1, Trace elements. J. Sediment. Res. 50, 1219-1236.

Brusnitsyn A. I. (2006) Mineralogy and metamorphism conditions of manganese ore at the South Faizulino deposit, the southern Urals, Russia. Geol. Ore Depos. 48, 193-214.

Büchel C., Barber J., Ananyev G., Eshaghi S., Watt R. and Dismukes C. (1999) Photoassembly of the Manganese Cluster and Oxygen Evolution from Monomeric and Dimeric CP47 Reaction Center Photosystem II Complexes. Proc. Natl. Acad. Sci. 96, 14288-14293.

Cairncross B. and Beukes N. J. (2013) The Kalahari Manganese Field, the adventure continues..., Struik Nature, Cape Town.

Calvert S. E. and Pedersen T. F. (1996) Sedimentary geochemistry of manganese; implications for the environment of formation of manganiferous black shales. Econ. Geol. 91, 36-47.

Calvert S. E. and Price N. B. (1970) Composition of manganese nodules and manganese carbonates from Loch Fyne, Scotland. Contrib. Mineral. Petrol. 29, 215-233.

Van Cappellen P., Viollier E., Roychoudhury A., Clark L., Ingali E., Lowe K. and Dichistrina T. (1998) Cycling of iron and manganese in surface sediments; a general theory for the coupled transport and reaction of carbon, oxygen, nitrogen, sulfur, iron, and manganese. Environ. Sci. Technol. 32, 2931-2939.

Cornell D. H. and Schütte S. S. (1995) A volcanic-exhalative origin for the world's largest (Kalahari) Manganese field. Miner. Deposita 30, 146-151. 
Damm K. L. Von (1990) Seafloor Hydrothermal Activity: Black Smoker Chemistry and Chimneys. Annu. Rev. Earth Planet. Sci. 18, 173.

Dasgupta S., Chakraborti S., Sengupta P., Bhattacharya P. K., Banerjee H., Roy S. and Fukuoka M. (1991) Manganese-rich minerals of the pumpellyite group from the Precambrian Sausar Group, India. Am. Mineral. 76, 241-245.

Davis D. W., Hirdes W., Schaltegger U. and Nunoo E. A. (1994) U-Pb age constraints on deposition and provenance of Birimian and gold-bearing Tarkwaian sediments in Ghana, West Africa. Precambrian Res. 67, 89-107.

Dick G. J., Clement B. G., Webb S. M., Fodrie F. J., Bargar J. R. and Tebo B. M. (2009) Enzymatic microbial Mn(II) oxidation and Mn biooxide production in the Guaymas Basin deep-sea hydrothermal plume. Geochim. Cosmochim. Acta 73, 6517-6530.

Elzinga E. J. (2011) Reductive Transformation of Birnessite by Aqueous Mn(II). Environ. Sci. Technol. 45, 6366-6372.

Fan D. and Yang P. (1999) Introduction to and classification of manganese deposits of China. Ore Geol. Rev. 15, 1-13.

Fischer T. B., Heaney P. J., Jang J.-H., Ross D. E., Brantley S. L., Post J. E. and Tien M. (2008) Continuous time-resolved X-ray diffraction of the biocatalyzed reduction of Mn oxide. Am. Mineral. 93, 1929-1932.

Fischer W. W. and Knoll A. H. (2009) An Iron Shuttle for Deepwater Silica in Late Archean and Early Paleoproterozoic Iron Formation. Geol. Soc. Am. Bull. 121, 222-235.

Fischer W. W., Schroeder S., Lacassie J. P., Beukes N. J., Goldberg T., Strauss H., Horstmann U. E., Schrag D. P. and Knoll A. H. (2009) Isotopic constraints on the Late Archean carbon cycle from the Transvaal Supergroup along the western margin of the Kaapvaal Craton, South Africa. Precambrian Res. 169, 15-27.

González F. J., Somoza L., León R., Medialdea T., de Torres T., Ortiz J. E., Lunar R., MartínezFrías J. and Merinero R. (2012) Ferromanganese nodules and micro-hardgrounds associated with the Cadiz Contourite Channel (NE Atlantic): Palaeoenvironmental records of fluid venting and bottom currents. Chem. Geol. 310-311, 56-78.

Gross G. A. (1965) Geology of Iron Deposits in Canada., Department of Mines and Technical Surveys, Geological Survey of Canada, Ottawa.

Grotzinger J. P. and Kasting J. F. (1993) New constraints on Precambrian ocean composition. $J$. Geol. 101, 235-243.

Gutzmer J. and Beukes N. J. (2000) Asbestiform manjiroite and todorokite from the Kalahari manganese field, South Africa. South Afr. J. Geol. 103, 163-174. 
Gutzmer J. and Beukes N. J. (1996a) Karst-hosted fresh-water Paleoproterozoic manganese deposits, Postmasburg, South Africa. Econ. Geol. 91, 1435-1454.

Gutzmer J. and Beukes N. J. (1996b) Mineral paragenesis of the Kalahari managanese field, South Africa. Ore Geol. Rev. 11, 405-428.

Hansel C. M., Zeiner C. A., Santelli C. M. and Webb S. M. (2012) Mn(II) oxidation by an ascomycete fungus is linked to superoxide production during asexual reproduction. Proc. Natl. Acad. Sci. 109, 12621-12625.

Hein J. R., Fan D., Ye J., Liu T. and Yeh H.-W. (1999) Composition and origin of Early Cambrian Tiantaishan phosphorite-Mn carbonate ores, Shaanxi Province, China. Ore Geol. Rev. 15, 95-134.

Hein J. R., Koschinsky A., Bau M., Manheim F. T., Kang J.-K. and Roberts L. (2000) Cobaltrich ferromanganese crusts in the Pacific. In Handbook of Marine Mineral Deposits (ed. D. S. Cronan). CRC Press, Boca Raton, Florida. pp. 239-279.

Hem J. D. and Lind C. J. (1983) Nonequilibrium models for predicting forms of precipitated manganese oxides. Geochim. Cosmochim. Acta 47, 2037-2046.

Hoffman P. F. (2013) The Great Oxidation and a Siderian snowball Earth: MIF-S based correlation of Paleoproterozoic glacial epochs. Chem. Geol. 362, 142-156.

Holland H. D. (1984) The Chemical Evolution of the Atmosphere and Oceans., Princeton University Press.

Horner T. J., Williams H. M., Hein J. R., Saito M. A., Burton K. W., Halliday A. N. and Nielsen S. G. (2015) Persistence of deeply sourced iron in the Pacific Ocean. Proc. Natl. Acad. Sci. 112, 1292-1297.

Ingle J. C. Jr., Suyehiro K., Breymann M. T. von and et al. (1990) Proceedings of the Ocean Drilling Program, Initial Reports., Ocean Drilling Program, College Station, TX.

Jakobsen R. and Postma D. (1989) Formation and solid solution behavior of Ca-rhodochrosites in marine muds of the Baltic deeps. Geochim. Cosmochim. Acta 53, 2639-2648.

Johnson J. E., Gerpheide A., Lamb M. P. and Fischer W. W. (2014) O2 constraints from Paleoproterozoic detrital pyrite and uraninite. Geol. Soc. Am. Bull. 126, 813-830.

Johnson J. E., Webb S. M., Thomas K., Ono S., Kirschvink J. L. and Fischer W. W. (2013) Manganese-oxidizing photosynthesis before the rise of cyanobacteria. Proc. Natl. Acad. Sci. 110, 11238-11243.

Jones S., McNaughton N. J. and Grguric B. (2013) Structural controls and timing of fault-hosted manganese at Woodie Woodie, East Pilbara, Western Australia. Ore Geol. Rev. 50, 5282. 
Kirschvink J. L., Gaidos E. J., Bertani L. E., Beukes N. J., Gutzmer J., Maepa L. N. and Steinberger R. E. (2000) Paleoproterozoic snowball Earth: Extreme climatic and geochemical global change and its biological consequences. Proc. Natl. Acad. Sci. 97, 1400-1405.

Klein C. and Ladeira E. A. (2004) Geochemistry and Mineralogy of Neoproterozoic Banded Iron-Formations and Some Selected, Siliceous Manganese Formations from the Urucum District, Mato Grosso Do Sul, Brazil. Econ. Geol. 99, 1233-1244.

Komiya T., Hirata T., Kitajima K., Yamamoto S., Shibuya T., Sawaki Y., Ishikawa T., Shu D., Li Y. and Han J. (2008) Evolution of the composition of seawater through geologic time, and its influence on the evolution of life. Gondwana Res. 14, 159-174.

Kostka J. E., Luther G. W. I. and Nealson K. H. (1995) Chemical and biological reduction of $\mathrm{Mn}(\mathrm{III})$-pyrophosphate complexes: Potential importance of dissolved $\mathrm{Mn}(\mathrm{III})$ as an environmental oxidant. Geochim. Cosmochim. Acta 59, 885-894.

Learman D. R., Voelker B. M., Vazquez-Rodriguez A. I. and Hansel C. M. (2011) Formation of manganese oxides by bacterially generated superoxide. Nat. Geosci. 4, 95-98.

Lee J.-H., Kennedy D. W., Dohnalkova A., Moore D. A., Nachimuthu P., Reed S. B. and Fredrickson J. K. (2011) Manganese sulfide formation via concomitant microbial manganese oxide and thiosulfate reduction. Environ. Microbiol. 13, 3275-3288.

Lin H., Szeinbaum N. H., DiChristina T. J. and Taillefert M. (2012) Microbial Mn(IV) reduction requires an initial one-electron reductive solubilization step. Geochim. Cosmochim. Acta 99, 179-192.

Lovley D. R. and Phillips E. J. P. (1988) Novel Mode of Microbial Energy Metabolism: Organic Carbon Oxidation Coupled to Dissimilatory Reduction of Iron or Manganese. Appl. Environ. Microbiol. 54, 1472-1480.

Lowenstein T. K., Timofeeff M. N., Brennan S. T., Hardie L. A. and Demicco R. V. (2001) Oscillations in Phanerozoic Seawater Chemistry: Evidence from Fluid Inclusions. Science 294, 1086-1088.

Luther G. W. I. (2010) The Role of One- and Two-Electron Transfer Reactions in Forming Thermodynamically Unstable Intermediates as Barriers in Multi-Electron Redox Reactions. Aquat. Geochem. 16, 395-420.

Madison A. S., Tebo B. M., Mucci A., Sundby B. and Luther G. W. (2013) Abundant Porewater $\mathrm{Mn}(\mathrm{III})$ Is a Major Component of the Sedimentary Redox System. Science 341, 875-878.

Martin D. M., Clendenin C. W., Krapez B. and McNaughton N. J. (1998) Tectonic and geochronological constraints on late Archaean and Palaeoproterozoic stratigraphic correlation within and between the Kaapvaal and Pilbara Cratons. J. Geol. Soc. Aust. 155, $311-322$. 
Martino I. (1986) The minerals industry of Mexico., International U.S. Bur. Mines, Washington, D.C.

Matsumoto R. (1992) Diagenetic Dolomite, Calcite, Rhodochrosite, Magnesite, and Lansfordite from site 799, Japan Sea - Implications for depositional environments and the diagenesis of organic-rich sediments. In Proceedings of the Ocean Drilling Program, Scientific Results (eds. K. A. Pisciotto, J. C. Ingle Jr., M. T. von Breymann, and J. Barron). Ocean Drilling Program, College Station, TX. pp. 75-98. Available at: doi:10.2973/odp.proc.sr.127128-1.119.1992.

Maxwell C. (1972) Geology and Ore Deposits of the Alegria District, Minas Gerais, Brazil., United States Government Printing Office, Washington, D.C.

Mayhew L. E., Webb S. M. and Templeton A. S. (2011) Microscale imaging and identification of Fe speciation and distribution during fluid-mineral reactions under highly reducing conditions. Environ. Sci. Technol. 45, 4468-4474.

Maynard J. B. (2010) The Chemistry of Manganese Ores through Time: A Signal of Increasing Diversity of Earth-Surface Environments. Econ. Geol. 105, 535-552.

McKeown D. A. and Post J. E. (2001) Characterization of manganese oxide mineralogy in rock varnish and dendrites using X-ray absorption spectroscopy. Am. Mineral. 86, 701-713.

Middelburg J. J., De Lange G. J. and van Der Weijden C. H. (1987) Manganese solubility control in marine pore waters. Geochim. Cosmochim. Acta 51, 759-763.

Morgan J. J. (2005) Kinetics of reaction between O2 and Mn(II) species in aqueous solutions. Geochim. Cosmochim. Acta 69, 35-48.

Mucci A. (2004) The Behavior of Mixed Ca-Mn Carbonates in Water and Seawater: Controls of Manganese Concentrations in Marine Porewaters. Aquat. Geochem. 10, 139-169.

Murray J. W., Dillard J. G., Giovanoli R., Moers H. and Stumm W. (1985) Oxidation of Mn(II): Initial mineralogy, oxidation state and ageing. Geochim. Cosmochim. Acta 49, 463-470.

Myers C. R. and Nealson K. H. (1988) Bacterial manganese reduction and growth with manganese oxide as the sole electron acceptor. Science 240, 1319-1321.

Myers C. R. and Nealson K. H. (1988) Microbial reduction of manganese oxides: Interactions with iron and sulfur. Geochim. Cosmochim. Acta 52, 2727-2732.

National Materials Advisory Board (1981) Manganese Reserves and Resources of the World and Their Industrial Implications., U.S. Department of the Interior, Washington, D.C.

Nel C. J., Beukes N. J. and De Villiers J. P. R. (1986) The Mamatwan manganese mine of the Kalahari Manganese Field. In Mineral deposits of Southern Africa (eds. C. R. Anhaeusser and S. Maske). Geological Society of South Africa. pp. 963-978. 
Neumann T., Heiser U., Leosson M. A. and Kersten M. (2002) Early diagenetic processes during Mn-carbonate formation: evidence from the isotopic composition of authigenic Carhodochrosites of the Baltic Sea. Geochim. Cosmochim. Acta 66, 867-879.

Okita P. M. (1992) Manganese carbonate mineralization in the Molango District, Mexico. Econ. Geol. 87, 1345-1366.

Okita P. M., Maynard J. B., Spiker E. C. and Force E. R. (1988) Isotopic evidence for organic matter oxidation by manganese reduction in the formation of stratiform manganese carbonate ore. Geochim. Cosmochim. Acta 52, 2679-2685.

Okita P. M. and Shanks W. C. (1992) Origin of stratiform sediment-hosted manganese carbonate ore deposits: Examples from Molango, Mexico, and TaoJiang, China. Chem. Geol. 99, 139-163.

Pedersen T. F. and Price N. B. (1982) The geochemistry of manganese carbonate in Panama Basin sediments. Geochim. Cosmochim. Acta 46, 59-68.

Perez J. and Jeffries T. W. (1992) Roles of manganese and organic acid chelators in regulating lignin degradation and biosynthesis of peroxidases by Phanerochaete chrysosporium. Appl. Environ. Microbiol. 58, 2402-2409.

Piacentini T., Vasconcelos P. M. and Farley K. A. (2013) 40Ar/39Ar constraints on the age and thermal history of the Urucum Neoproterozoic banded iron-formation, Brazil.

Precambrian Res. 228, 48-62.

Polgári M., Bajnóczi B., Kovács Kis V., Götze J., Dobosi G., Tóth M. and Vigh T. (2007) Mineralogical and cathodoluminescence characteristics of Ca-rich kutnohorite from the Úrkút Mn-carbonate mineralization, Hungary. Mineral. Mag. 71, 493-508.

Polgári M., Okita P. M. and Hein J. R. (1991) Stable Isotope Evidence for the Origin of the Úrkút Manganese Ore Deposit, Hungary. J. Sediment. Petrol. 61, 384-393.

Post J. E. (1999) Manganese oxide minerals: Crystal structures and economic and environmental significance. Proc. Natl. Acad. Sci. 96, 3447-3454.

Pracejus B. and Bolton B. R. (1992) Geochemistry of supergene manganese oxide deposits, Groote Eylandt, Australia. Econ. Geol. 87, 1310-1335.

Rao A. M. F., Polerecky L., Ionescu D., Meysman F. J. R. and de Beer D. (2012) The influence of pore-water advection, benthic photosynthesis, and respiration on calcium carbonate dynamics in reef sands. Limnol. Oceanogr. 57, 809-825.

Robie R. A., Huebner J. S. and Hemingway B. S. (1995) Heat capacities and thermodynamic properties of braunite (Mn7SiO12) and rhodonite (MnSiO3). Am. Mineral. 80, 560-575. 
Rodionov S. M., Obolenskiy A. A., Distanov E. G., Badarch G., Dejidmaa G., Duk H. H., Khanchuk A. I., Ogasawara M., Nokleberg W. J., Parfenov L. M. and et al. (2004) Descriptions of Northeast Asia Metallogenic Belts., United States Geological Survey.

Roy S. (2006) Sedimentary manganese metallogenesis in response to the evolution of the Earth system. Earth-Sci. Rev. 77, 273-305.

Schneiderhan E. A., Gutzmer J., Strauss H., Mezger K. and Beukes N. J. (2006) The Chemostratigraphy of a Paleoproterozoic MnF- BIF Succession -the Voëlwater Subgroup of the Transvaal Supergroup in Griqualand West, South Africa. South Afr. J. Geol. 109, 63-80.

Schröder S., Bedorf D., Beukes N. J. and Gutzmer J. (2011) From BIF to red beds: Sedimentology and sequence stratigraphy of the Paleoproterozoic Koegas Subgroup (South Africa). Sediment. Geol. 236, 25-44.

Scott R. W. (1984) Mesozoic Biota and Depositional Systems of the Gulf of Mexico-Caribbean Region. In Jurassic-Cretaceous Biochronology and Paleogeography of North America (ed. G. E. G. Westermann). Geological Association of Canada. University of Toronto Press, St. John's, Newfoundland.

Takehara M., Komure M., Kiyokawa S., Horie K. and Yokohama K. (2010) Detrital zircon SHRIMP U-Pb age of the $2.3 \mathrm{Ga}$ diamictites of the Meteorite Bore Member in the South Pilbara, Western Australia. In Fifth International Archean Symposium Abstracts: Geological Survey of Western Australia (eds. I. M. Tyler and C. M. Knox-Robinson). Record 2010/18. pp. 223-224.

Taljaardt J. J. (1982) Major manganese ore fields, Republic of South Africa., SAMANCOR, Johannesburg.

Tamura N. and Cheniae G. (1987) Photoactivation of the water-oxidizing complex in Photosystem II membranes depleted of Mn and extrinsic proteins. I. Biochemical and kinetic characterization. Biochim. Biophys. Acta BBA - Bioenerg. 890, 179-194.

Tang Y., Zeiner C. A., Santelli C. M. and Hansel C. M. (2013) Fungal oxidative dissolution of the $\mathrm{Mn}(\mathrm{II})$-bearing mineral rhodochrosite and the role of metabolites in manganese oxide formation. Environ. Microbiol. 15, 1063-1077.

Tebo B. M., Bargar J. R., Clement B. G., Dick G. J., Murray K. J., Parker D., Verity R. and Webb S. M. (2004) BIOGENIC MANGANESE OXIDES: Properties and Mechanisms of Formation. Annu. Rev. Earth Planet. Sci. 32, 287-328.

Tebo B. M., Johnson H. A., McCarthy J. K. and Templeton A. S. (2005) Geomicrobiology of manganese(II) oxidation. Trends Microbiol. 13, 421-428.

Thamdrup B., Finster K., Hansen J. W. and Bak F. (1993) Bacterial Disproportionation of Elemental Sulfur Coupled to Chemical Reduction of Iron or Manganese. Appl. Environ. Microbiol. 59, 101-108. 
Thamdrup B., Rosselló-Mora R. and Amann R. (2000) Microbial Manganese and Sulfate Reduction in Black Sea Shelf Sediments. Appl. Environ. Microbiol. 66, 2888-2897.

Tsikos H., Beukes N. J., Moore J. M. and Harris C. (2003) Deposition, Diagenesis, and Secondary Enrichment of Metals in the Paleoproterozoic Hotazel Iron Formation, Kalahari Manganese Field, South Africa. Econ. Geol. 98, 1449-1462.

Turekian K. K. and Wedepohl K. H. (1961) Distribution of the Elements in Some Major Units of the Earth's Crust. Geol. Soc. Am. Bull. 72, 175-192.

Urban H., Stribrny B. and Lippolt H. J. (1992) Iron and manganese deposits of the Urucum District, Mato Grosso do Sul, Brazil. Econ. Geol. 87, 1375-1392.

Varentsov I. M. and Grasselly G. eds. (1976) Geology and geochemistry of manganese: proceedings of the 2nd International Symposium on Geology and Geochemistry of Manganese., International Symposium on Geology and Geochemistry of Manganese, Sydney.

Vasconcelos P. M. (1999) K-Ar AND 40Ar/39Ar GEOCHRONOLOGY OF WEATHERING PROCESSES. Annu. Rev. Earth Planet. Sci. 27, 183-229.

Veizer J. (1978) Secular variations in the composition of sedimentary carbonate rocks, II. Fe, $\mathrm{Mn}, \mathrm{Ca}, \mathrm{Mg}, \mathrm{Si}$ and minor constituents. Precambrian Res. 6, 381-413.

Wariishi H., Valli K. and Gold M. H. (1992) Manganese(II) oxidation by manganese peroxidase from the basidiomycete Phanerochaete chrysosporium. Kinetic mechanism and role of chelators. J. Biol. Chem. 267, 23688-23695.

Webb S. M. (2011) The MicroAnalysis Toolkit: X-ray Fluorescence Image Processing Software. AIP Conf. Proc. 1365, 196-199.

Webb S. M., Dick G. J., Bargar J. R. and Tebo B. M. (2005) Evidence for the presence of Mn(III) intermediates in the bacterial oxidation of Mn(II). Proc. Natl. Acad. Sci. U. S. A. 102, 5558-5563.

Webb S. M., Tebo B. M. and Bargar J. R. (2005) Structural characterization of biogenic Mn oxides produced in seawater by the marine bacillus sp. strain SG-1. Am. Mineral. 90, 1342-1357.

Wehrli B., Friedl G. and Manceau A. (1995) Reaction Rates and Products of Manganese Oxidation at the Sediment-Water Interface. In Aquatic Chemistry Advances in Chemistry. American Chemical Society. pp. 111-134. Available at: http://dx.doi.org/10.1021/ba1995-0244.ch005 [Accessed November 9, 2014].

Wenzhöfer F., Adler M., Kohls O., Hensen C., Strotmann B., Boehme S. and Schulz H. D. (2001) Calcite dissolution driven by benthic mineralization in the deep-sea: in situ measurements of $\mathrm{Ca} 2+, \mathrm{pH}, \mathrm{pCO} 2$ and O2. Geochim. Cosmochim. Acta 65, 2677-2690. 
White D. (2007) The Physiology and Biochemistry of Prokaryotes. 3rd edition., Oxford University Press, Oxford.

Williford K. H., Van Kranendonk M. J., Ushikubo T., Kozdon R. and Valley J. W. (2011) Constraining atmospheric oxygen and seawater sulfate concentrations during Paleoproterozoic glaciation: In situ sulfur three-isotope microanalysis of pyrite from the Turee Creek Group, Western Australia. Geochim. Cosmochim. Acta 75, 5686-5705.

Ying S. C., Kocar B. D., Griffis S. D. and Fendorf S. (2011) Competitive Microbially and Mn Oxide Mediated Redox Processes Controlling Arsenic Speciation and Partitioning. Environ. Sci. Technol. 45, 5572-5579. 


\begin{tabular}{|c|c|c|c|}
\hline Ore Name/Location & $\begin{array}{l}\text { Volume } \\
\text { (million } \\
\text { tons) }\end{array}$ & $\begin{array}{l}\text { Estimated } \\
\text { Age (million } \\
\text { years ago) }\end{array}$ & Reference \\
\hline $\begin{array}{c}\text { Nikopol, Ukraine, } \\
\text { Georgia }\end{array}$ & 1000 & 28 & $\begin{array}{c}\text { Varentsov and Grasselly, } \\
1976\end{array}$ \\
\hline $\begin{array}{c}\text { Groote Eylandt, } \\
\text { Australia } \\
\end{array}$ & 400 & 123 & Pracejus and Bolton, 1992 \\
\hline Molango, Mexico & 200 & 155 & Martino, 1986 \\
\hline $\begin{array}{c}\text { Xialei, China + Atasu, } \\
\text { Kazakhstan }\end{array}$ & 200 & 370 & $\begin{array}{l}\text { Varentsov and Grasselly, } \\
\text { 1976; Fan and Yang, } 1999\end{array}$ \\
\hline Usinsk, Siberia + others & 150 & 520 & $\begin{array}{c}\text { Varentsov and Grasselly, } \\
1976\end{array}$ \\
\hline $\begin{array}{c}\text { Corumbá, Brazil + small } \\
\text { Baltic deps }\end{array}$ & 686 & 625 & Urban et al, 1992 \\
\hline $\begin{array}{c}\text { Woodie-Woodie, East } \\
\text { Pilbara, Australia }\end{array}$ & 65 & $1100-950$ & Jones et al, 2013 \\
\hline Wafangzi, China & 38 & 1200 & Rodionov et al, 2004 \\
\hline $\begin{array}{l}\text { Sausar Group, India + } \\
\text { Postmasburg Group }\end{array}$ & 115 & 2000 & $\begin{array}{l}\text { Dasgupta et al, 1991; } \\
\text { Guzmer and Beukes, 1996a; } \\
\text { Cairncross and Beukes, } \\
2013\end{array}$ \\
\hline Moanda, Gabon & 400 & 2150 & $\begin{array}{c}\text { National Materials Advisory } \\
\text { Board, 1981; Gauthier- } \\
\text { Lafaye et al, } 1996\end{array}$ \\
\hline $\begin{array}{c}\text { Birimian Supergroup, } \\
\text { West Africa }\end{array}$ & 49 & 2200 & $\begin{array}{c}\text { National Materials Advisory } \\
\text { Board, 1981; Davis et al, } \\
1994\end{array}$ \\
\hline $\begin{array}{l}\text { Hotazel Formation/ } \\
\text { Kalahari Mn field }\end{array}$ & 1350 & 2220 & $\begin{array}{c}\text { Gutzmer and Beukes, } \\
\text { 1996b; Taljaardt, } 1982\end{array}$ \\
\hline Minas Gerais, Brazil & 20 & 2400 & $\begin{array}{c}\text { Maxwell, 1972; Babinski et } \\
\text { al., } 1995 \\
\end{array}$ \\
\hline $\begin{array}{c}\text { Koegas Subgroup, } \mathrm{S} \\
\text { Africa }\end{array}$ & 200 & 2420 & $\begin{array}{l}\text { Cairncross and Beukes, } \\
2013\end{array}$ \\
\hline
\end{tabular}

Table 1 - Accompanying Figure 1, we present a compilation of significant manganese ore deposits through time and estimates from the literature of their respective manganese volume and estimated age. Reference(s) used presented on right column. 


\begin{tabular}{|c|c|c|c|c|c|}
\hline $\begin{array}{l}\text { Deposit } \\
\text { Name }\end{array}$ & Location & Age & $\begin{array}{l}\text { Geologic } \\
\text { Setting }\end{array}$ & $\begin{array}{l}\text { Redox } \\
\text { state }\end{array}$ & Mn minerals \\
\hline $\begin{array}{c}\text { Ferro- } \\
\text { manganese } \\
\text { nodule }\end{array}$ & $\begin{array}{l}\text { South } \\
\text { Pacific } \\
\text { Gyre }\end{array}$ & modern & ocean floor & $\mathrm{Mn}(\mathrm{IV})$ & birnessite-like \\
\hline $\begin{array}{l}\text { Japan Sea } \\
\text { core }\end{array}$ & $\begin{array}{l}\text { Japan } \\
\text { Sea }\end{array}$ & $\begin{array}{l}\text { Pliocene- } \\
\text { Miocene } \\
\text { ( 11 Ma) }\end{array}$ & $\begin{array}{l}\text { organic- } \\
\text { rich failed } \\
\text { rift basin }\end{array}$ & $\mathrm{Mn}(\mathrm{II})$ & $\begin{array}{c}\text { magnesite, siderite, } \\
\text { manganoan } \\
\text { calcite/kutnohorite, } \\
\text { calcian } \\
\text { rhodochrosite }\end{array}$ \\
\hline $\begin{array}{l}\text { Molango } \\
\text { deposit }\end{array}$ & Mexico & $\begin{array}{c}\text { Upper } \\
\text { Jurassic } \\
\text { ( 155 Ma) }\end{array}$ & $\begin{array}{l}\text { carbonate } \\
\text { platform } \\
\text { shelf }\end{array}$ & $\mathrm{Mn}(\mathrm{II})$ & $\begin{array}{l}\text { rhodochrosite, } \\
\text { manganoan calcite }\end{array}$ \\
\hline $\begin{array}{l}\text { Santa Cruz } \\
\text { deposit }\end{array}$ & $\begin{array}{l}\text { Jacadigo } \\
\text { Basin, } \\
\text { Brazil }\end{array}$ & $\begin{array}{l}\text { Neoprot- } \\
\text { erozoic } \\
\text { (889- } \\
587 \mathrm{Ma})\end{array}$ & $\begin{array}{l}\text { continental } \\
\text { rift basin, } \\
\text { lacustrine } \\
\text { or marine } \\
\text { gulf } \\
\end{array}$ & $M n(I I, I I I)$ & $\begin{array}{l}\text { braunite, } \\
\text { rhodochrosite, } \\
\text { kutnohorite, } \\
\text { caryopilite }\end{array}$ \\
\hline & \multicolumn{3}{|c|}{ weathered } & $\mathrm{Mn}(\mathrm{IV})$ & $\begin{array}{l}\text { cryptomelane (or } \\
\text { birnessite) }\end{array}$ \\
\hline $\begin{array}{l}\text { Hotazel } \\
\text { Formation }\end{array}$ & $\begin{array}{l}\text { South } \\
\text { Africa }\end{array}$ & $\sim 2200 \mathrm{Ma}$ & $\begin{array}{l}\text { marine } \\
\text { back-arc } \\
\text { basin or } \\
\text { proximal } \\
\text { mid-ocean } \\
\text { ridge }\end{array}$ & $\mathrm{Mn}(\mathrm{II}, \mathrm{III})$ & $\begin{array}{c}\text { braunite, } \\
\text { kutnohorite, } \\
\text { manganoan calcite }\end{array}$ \\
\hline \multirow[t]{2}{*}{$\begin{array}{l}\text { Koegas } \\
\text { Subgroup }\end{array}$} & $\begin{array}{l}\text { South } \\
\text { Africa }\end{array}$ & $\sim 2415 \mathrm{Ma}$ & $\begin{array}{c}\text { deltaic } \\
\text { near-shore } \\
\text { marine }\end{array}$ & $\mathrm{Mn}(\mathrm{II})$ & $\begin{array}{c}\text { ferrous } \\
\text { rhodochrosite, } \\
\text { manganoan siderite, } \\
\text { manganoan calcite }\end{array}$ \\
\hline & \multicolumn{3}{|c|}{ weathered } & $\mathrm{Mn}(\mathrm{IV})$ & $\begin{array}{l}\text { cryptomelane or } \\
\text { birnessite }\end{array}$ \\
\hline \multirow{2}{*}{$\begin{array}{l}\text { Kungarra } \\
\text { Formation }\end{array}$} & Australia & $\begin{array}{c}2420- \\
2209 \mathrm{Ma}\end{array}$ & $\begin{array}{l}\text { Glacio- } \\
\text { marine }\end{array}$ & \multicolumn{2}{|c|}{ (no subsurface samples) } \\
\hline & \multicolumn{3}{|c|}{ weathered } & $\mathrm{Mn}(\mathrm{IV})$ & $\begin{array}{c}\text { cryptomelane or } \\
\text { birnessite }\end{array}$ \\
\hline
\end{tabular}

Table 2 - A summary table of the seven deposits analyzed in this study, including their location, estimated age, geologic setting, and the redox and mineralogical results determined by this study. 
Figure1

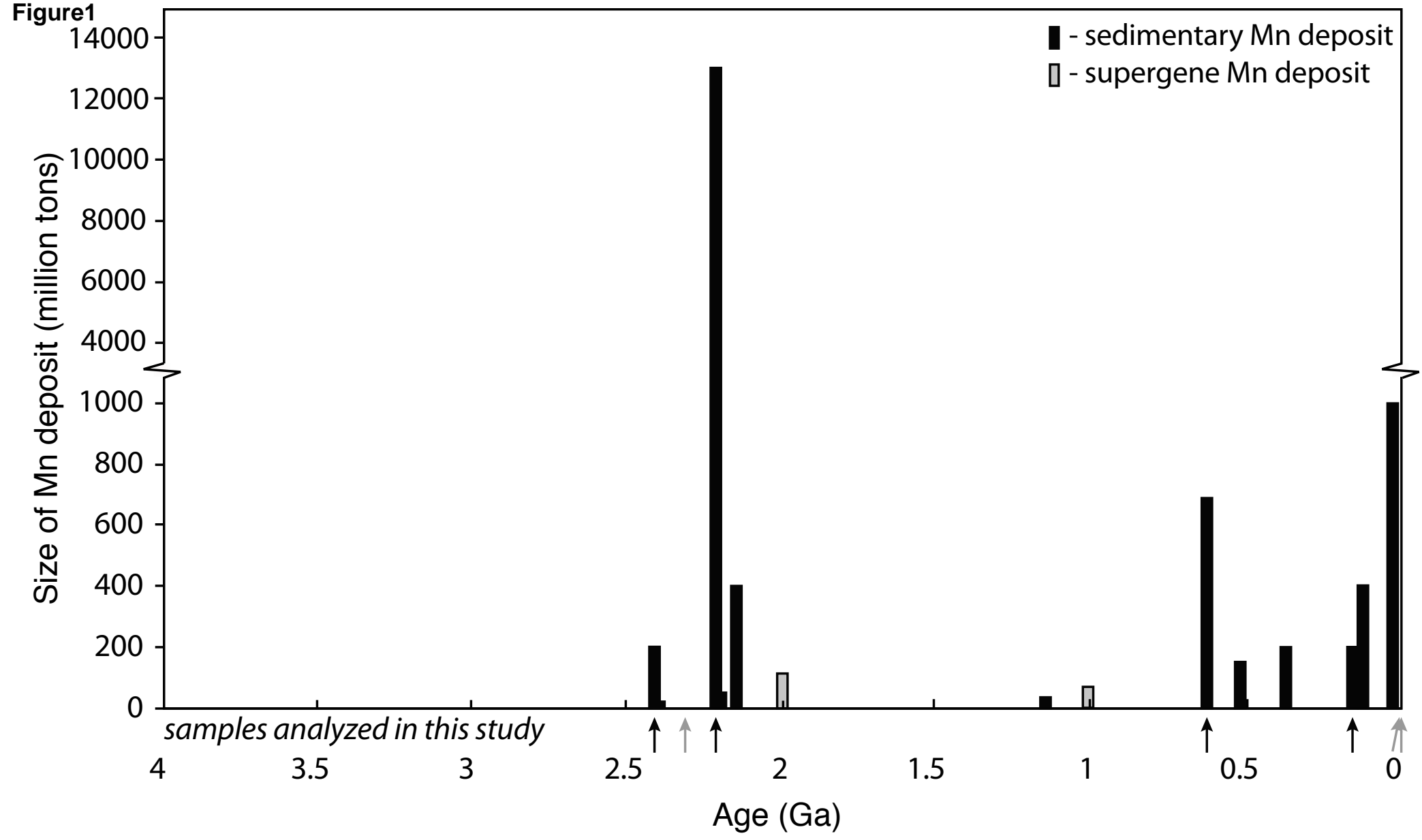



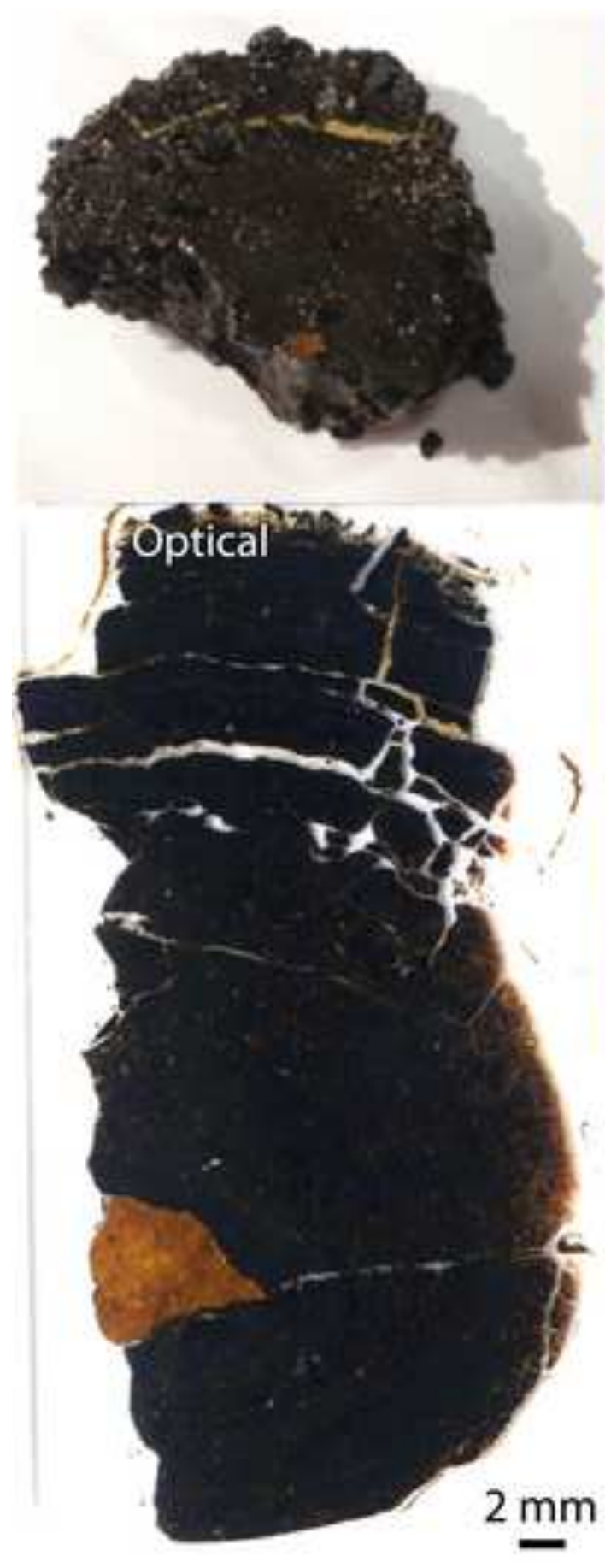
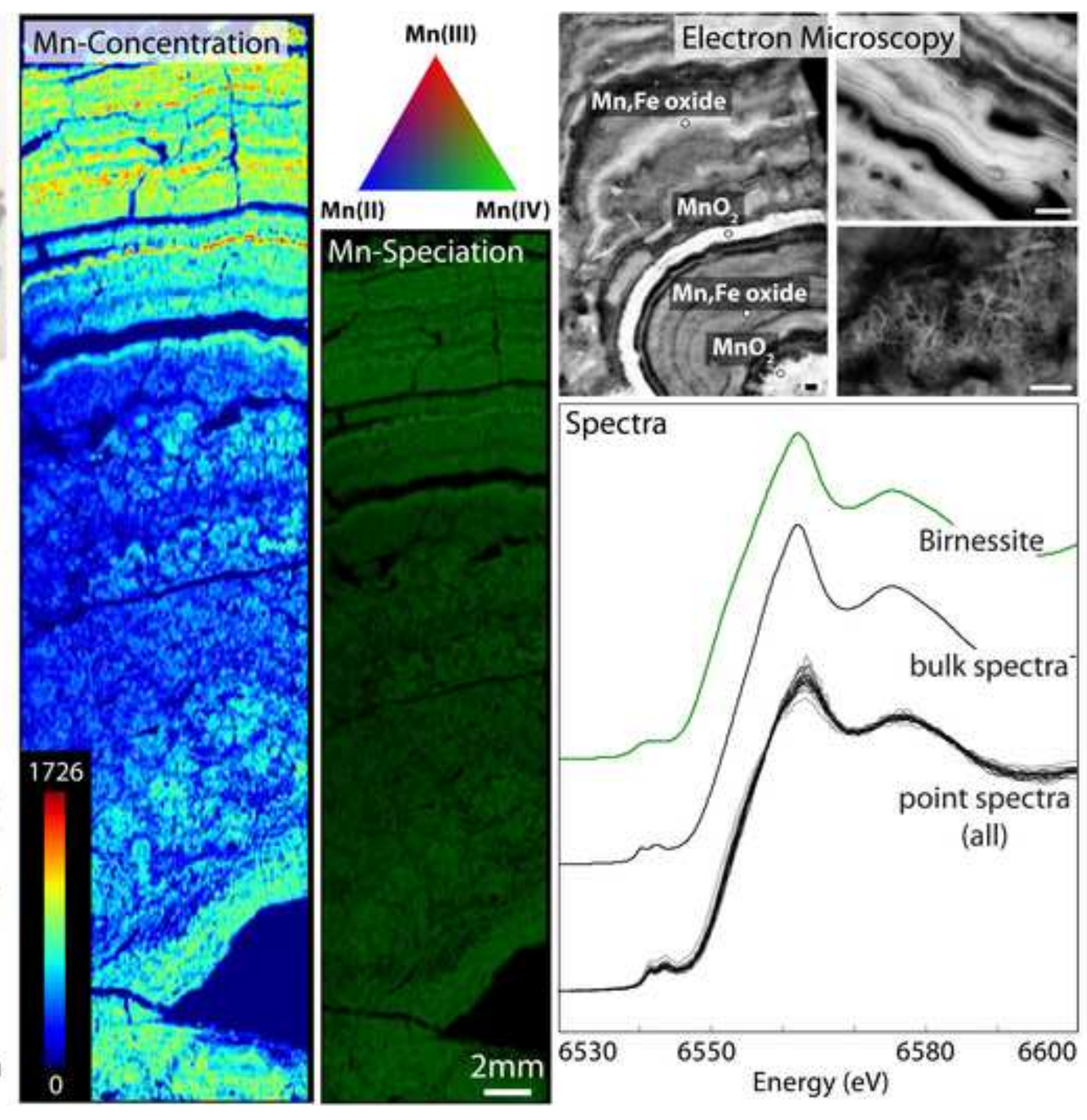

Mn-Speciation
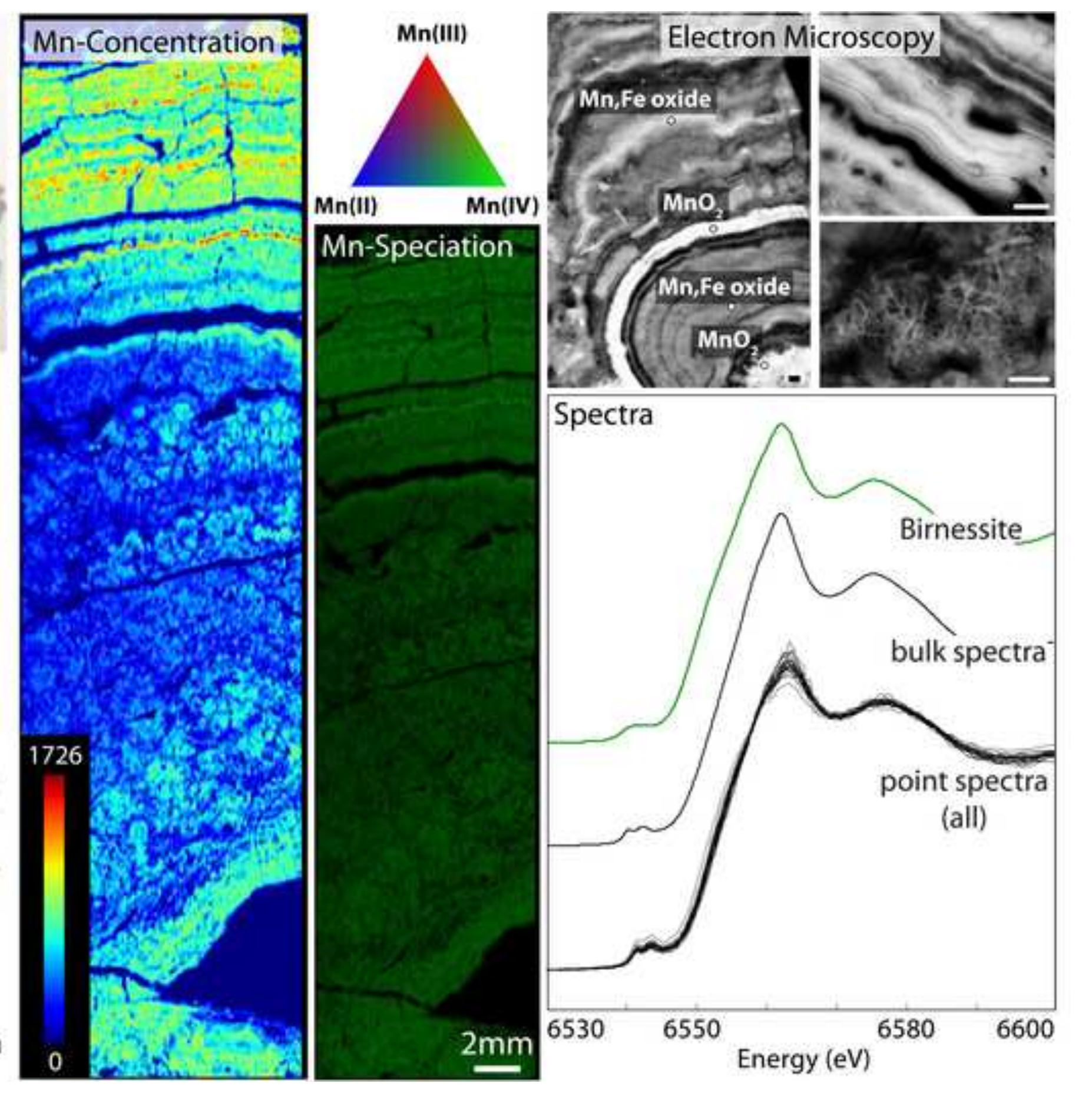

\section{Spectra}

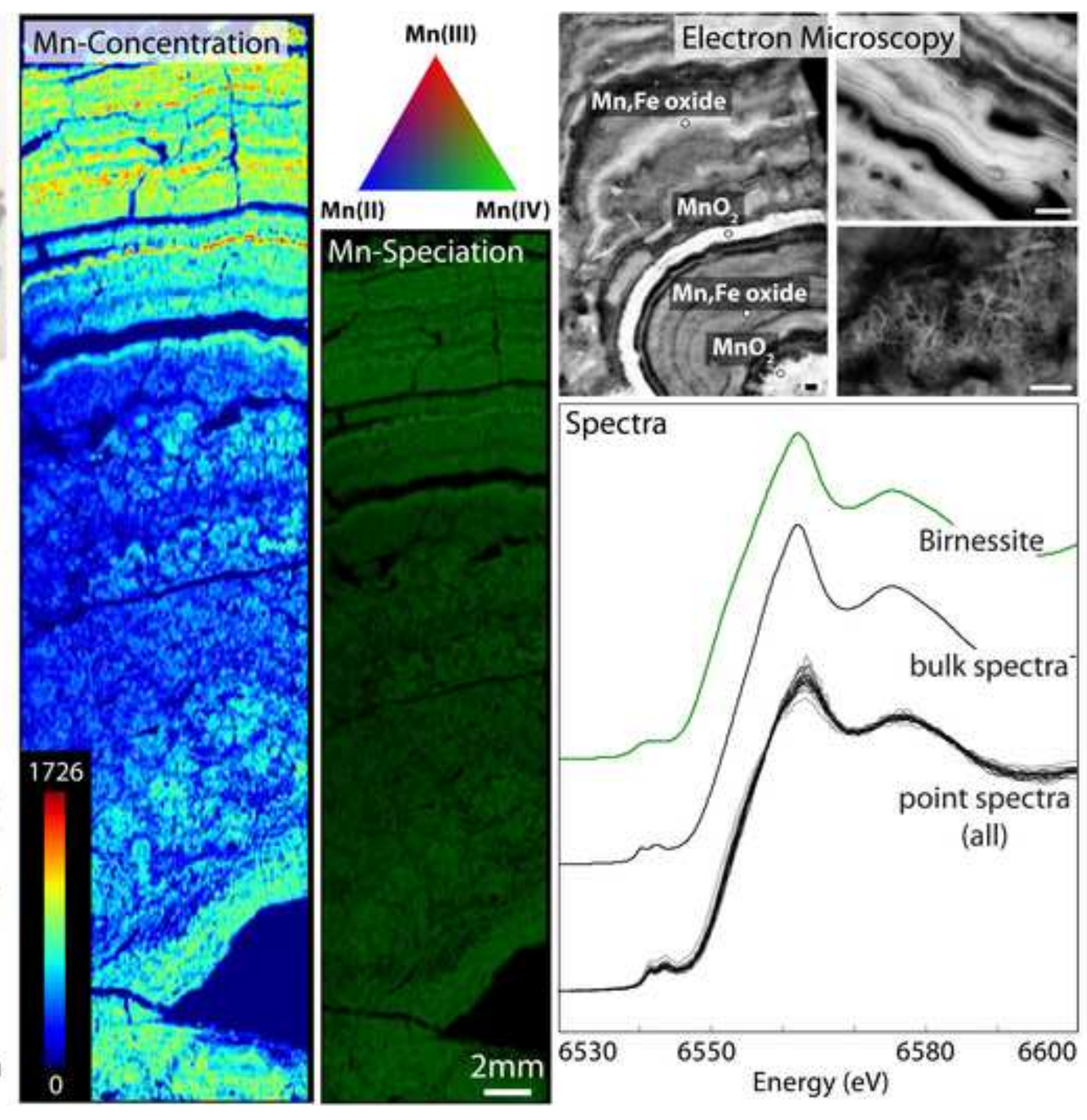

(all)
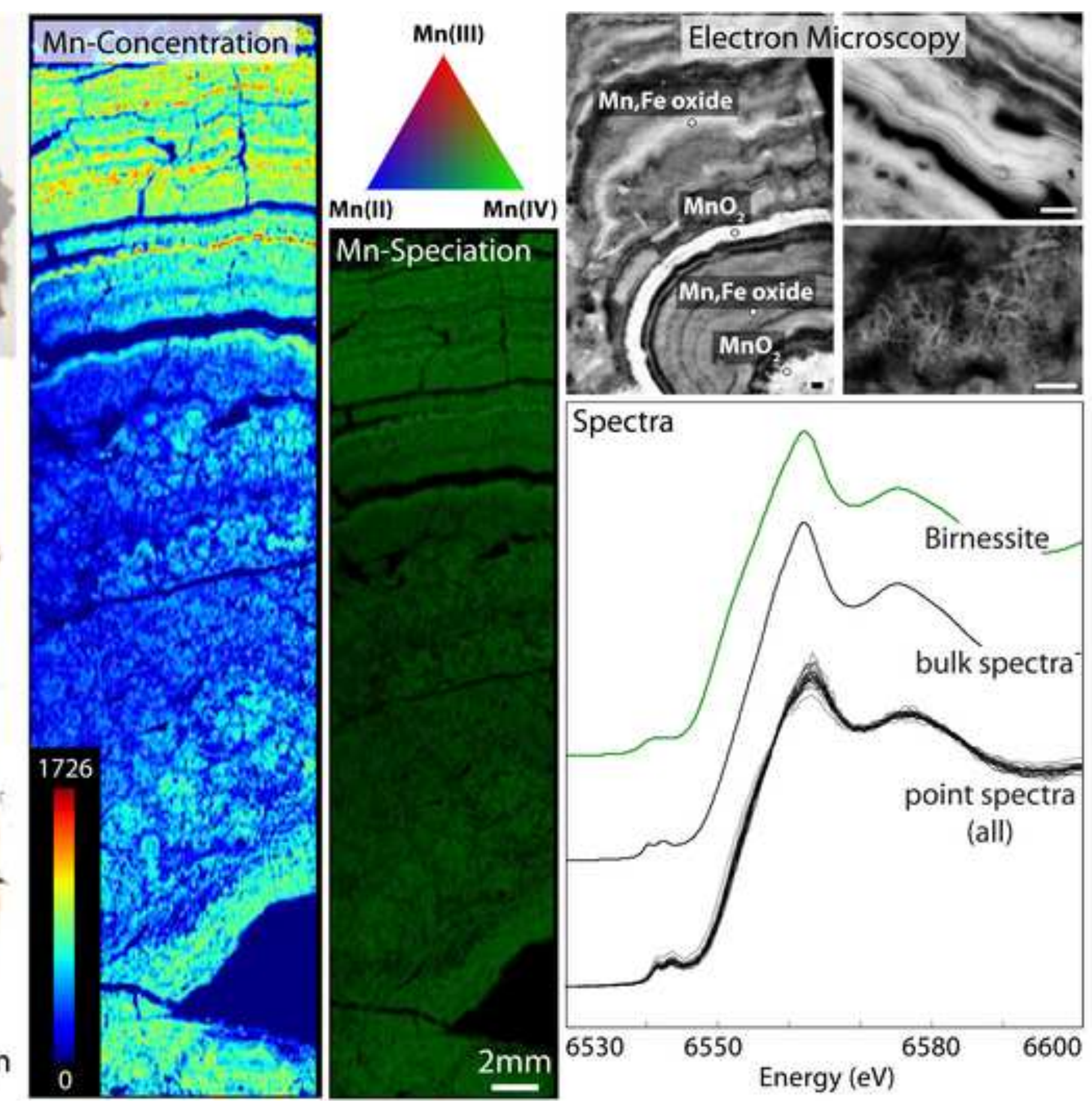

$$
\text { Energy (eV) }
$$

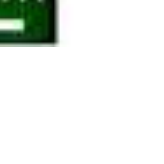



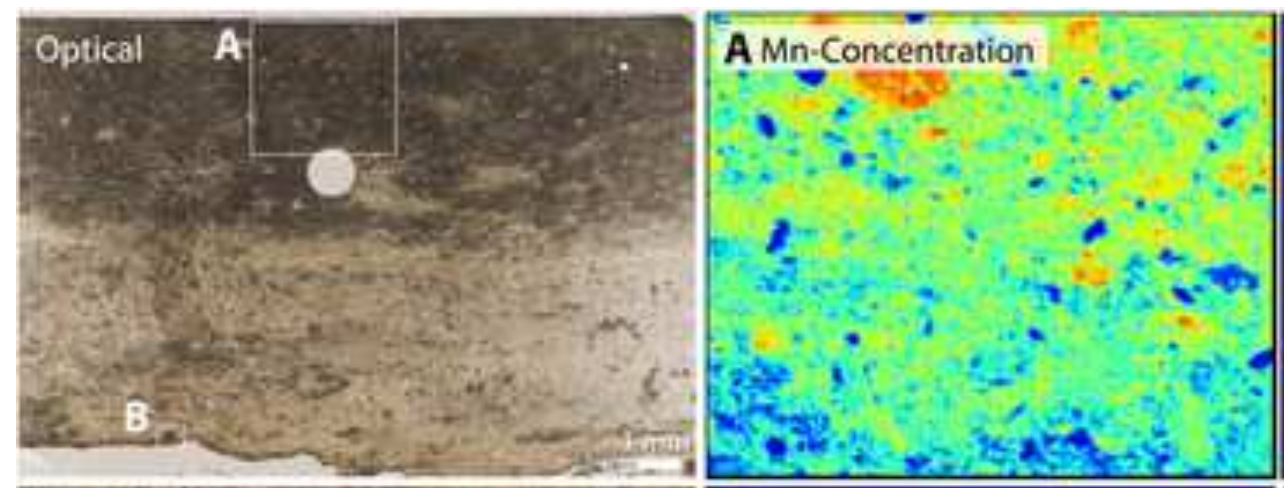

Mn-Redox
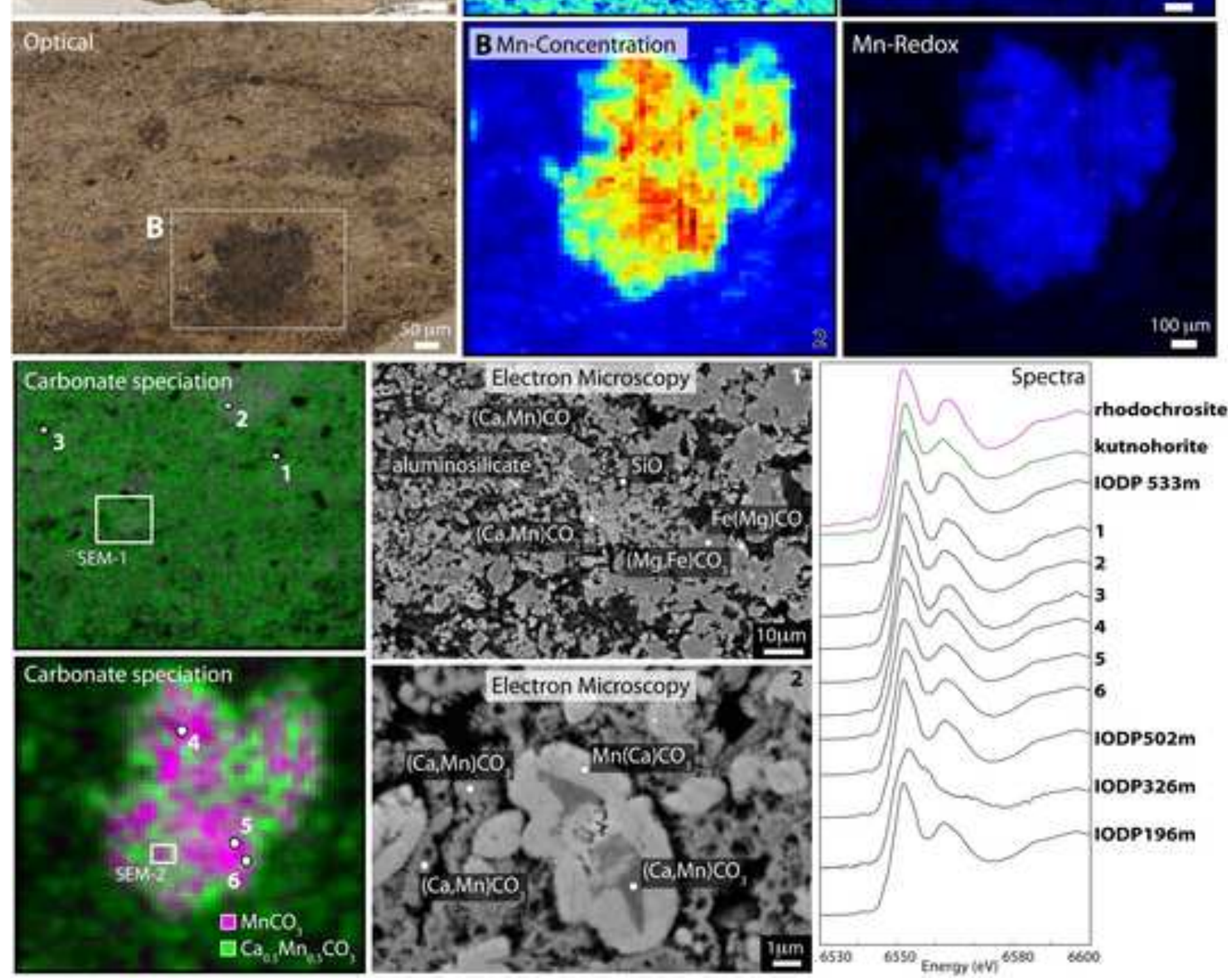


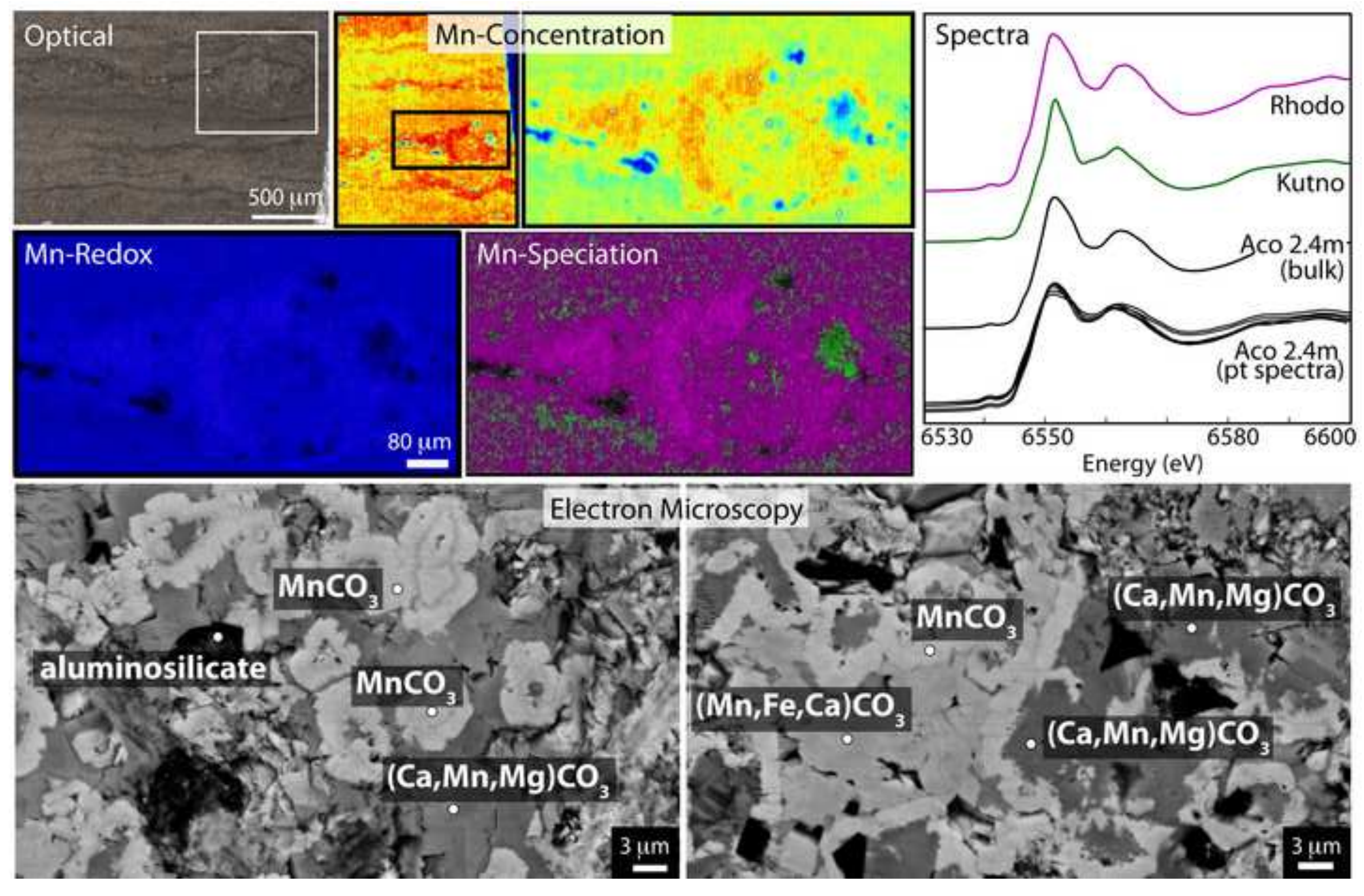

.

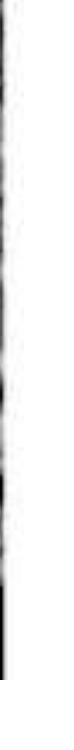

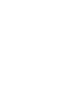




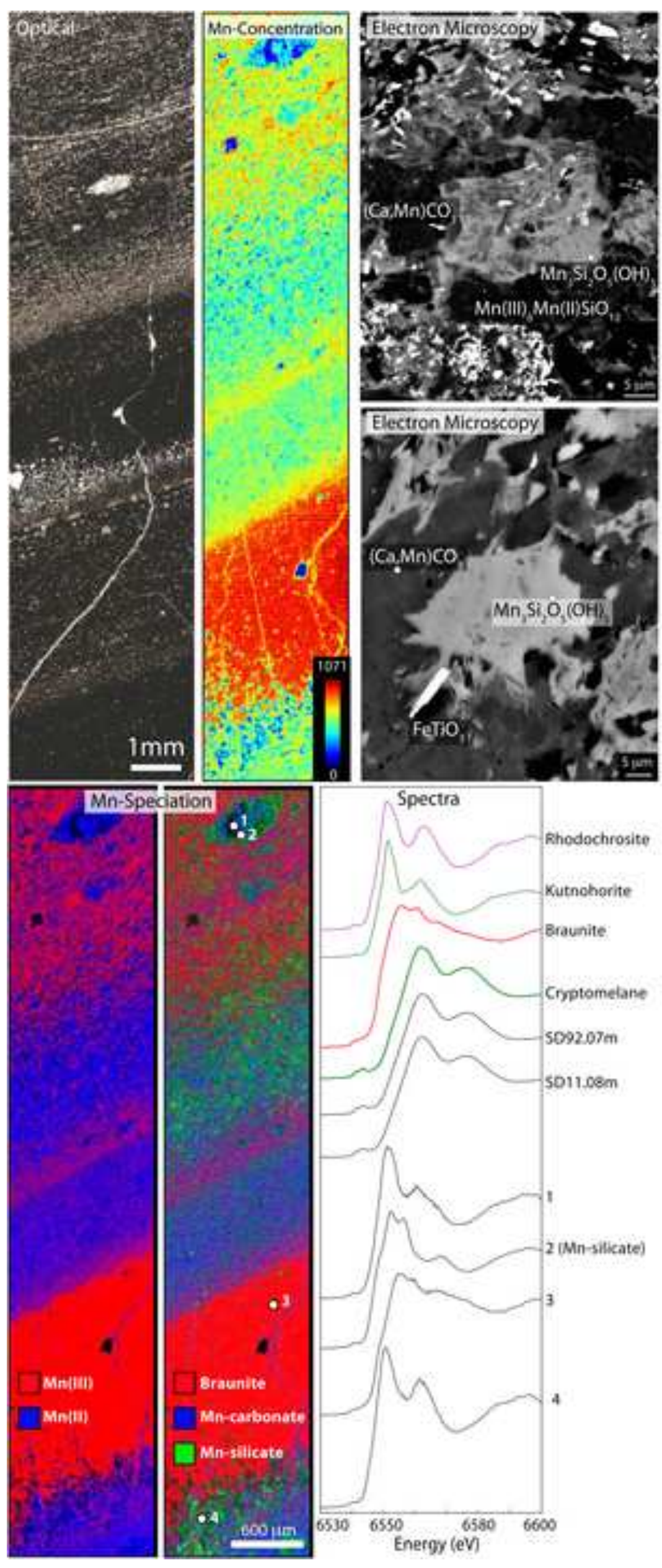

Figure6 


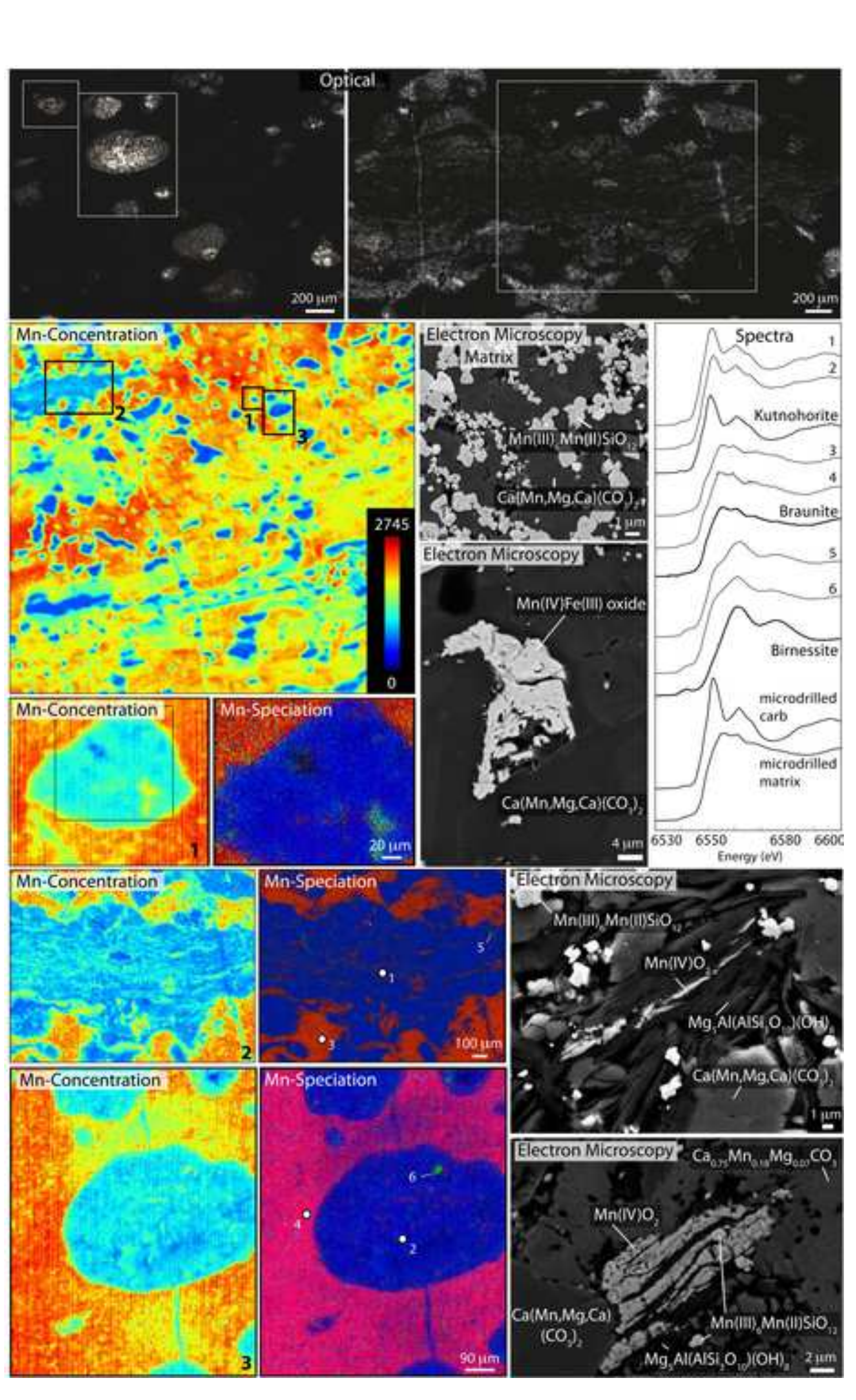




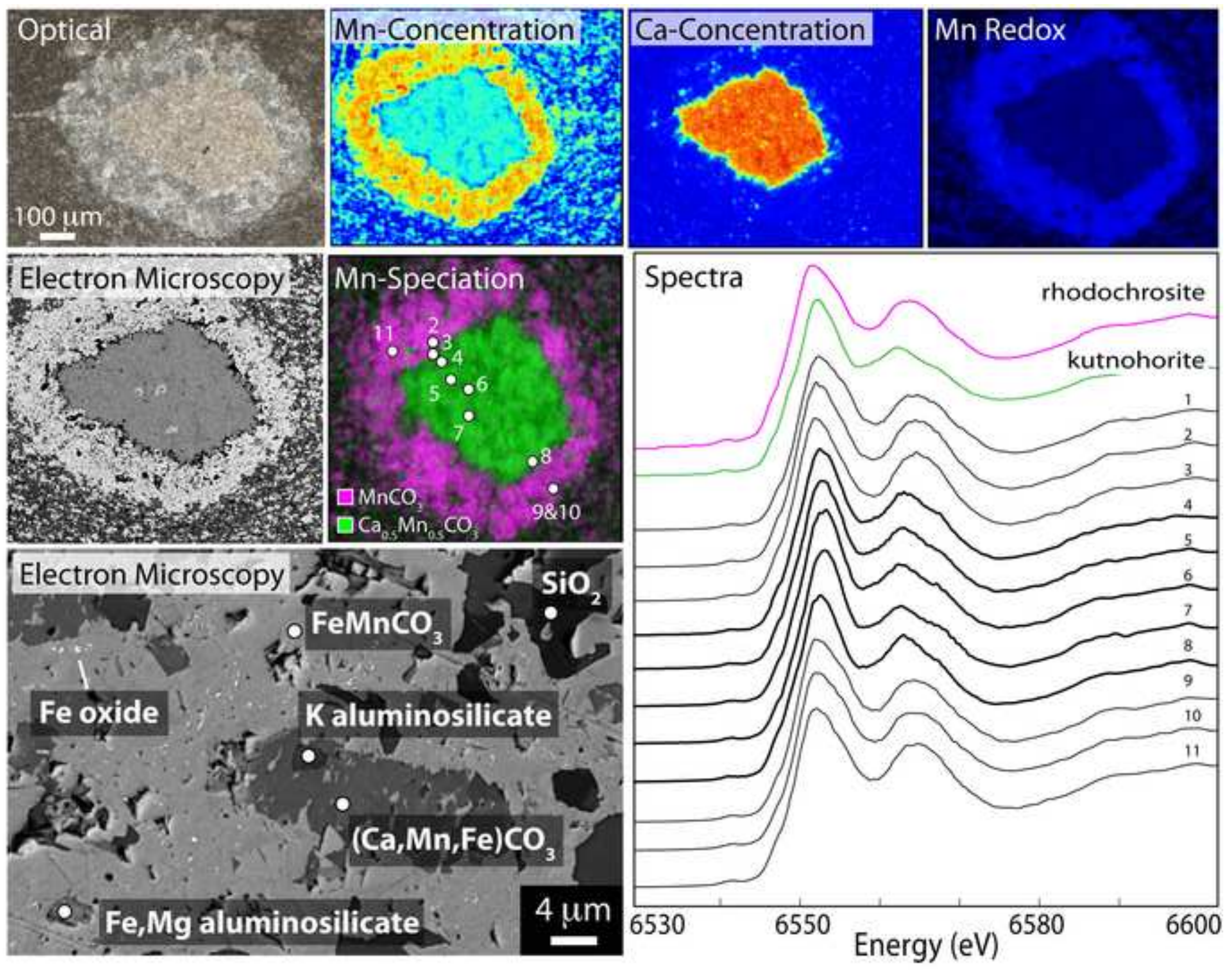



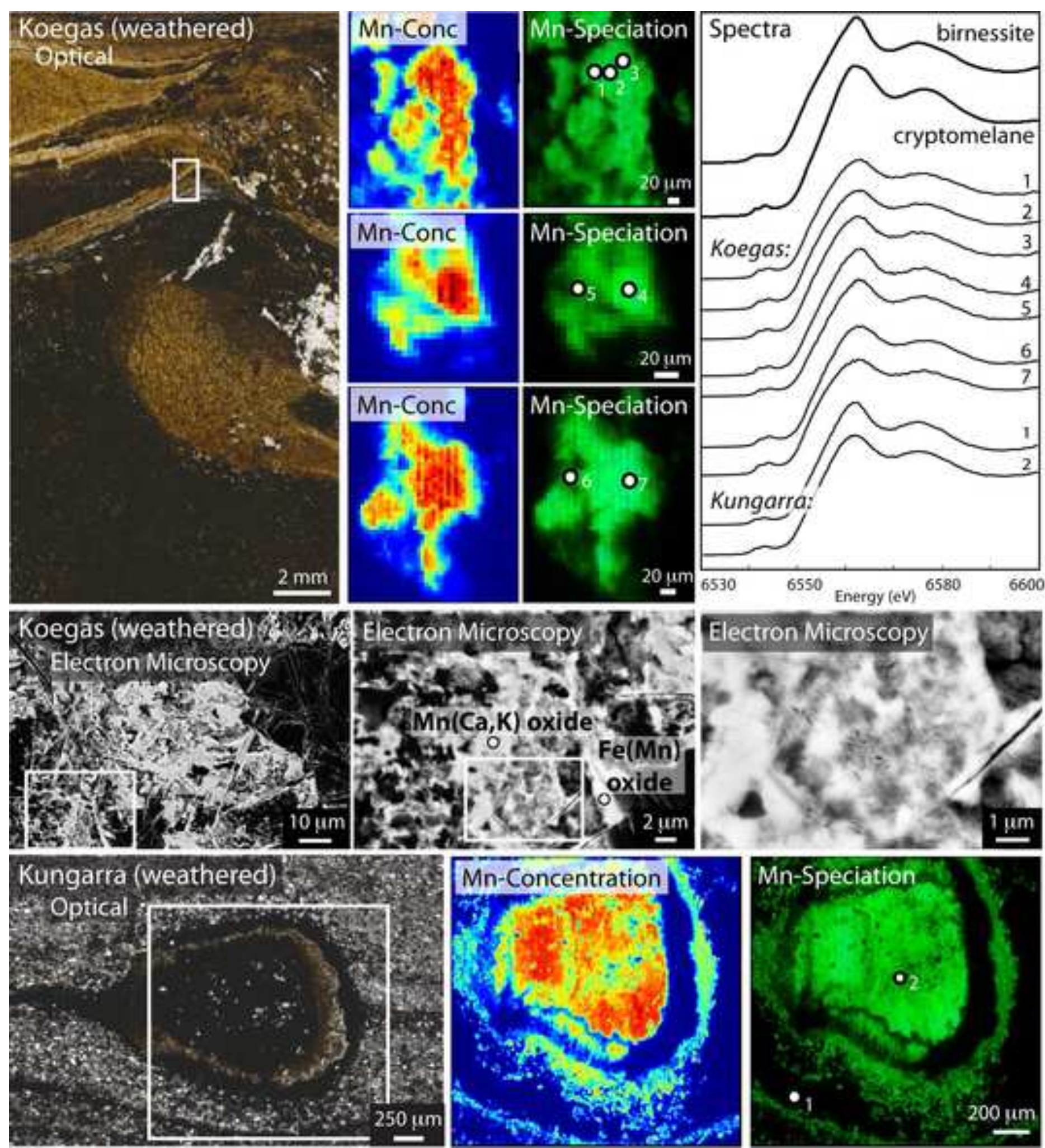
Mn(IV) oxides

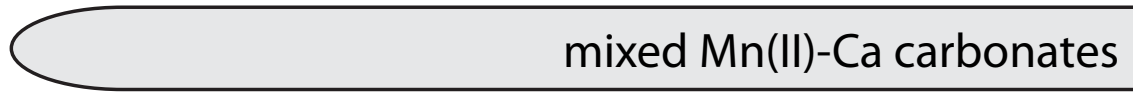

$\mathrm{Mn}$ (III)OOH or $\mathrm{Mn}$ (III)-ligand

Rhodochrosite $\left(\mathrm{MnCO}_{3}\right)$

Braunite (Mn(III) $\left.{ }_{6} \mathrm{Mn}(\mathrm{II}) \mathrm{O}_{8} \mathrm{SiO}_{4}\right)$

$\mathrm{Mn}(\mathrm{II}) \mathrm{SiO} 3 . .$.

Time/Burial 


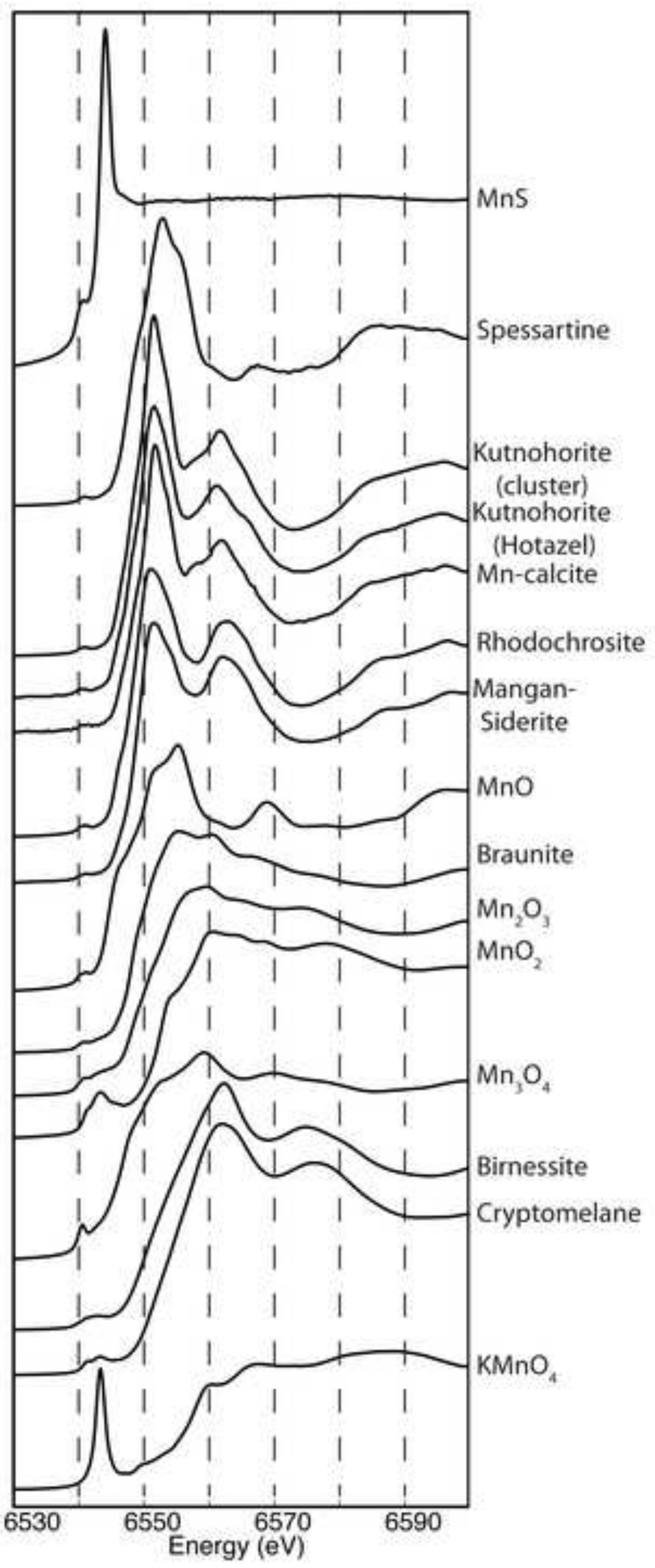



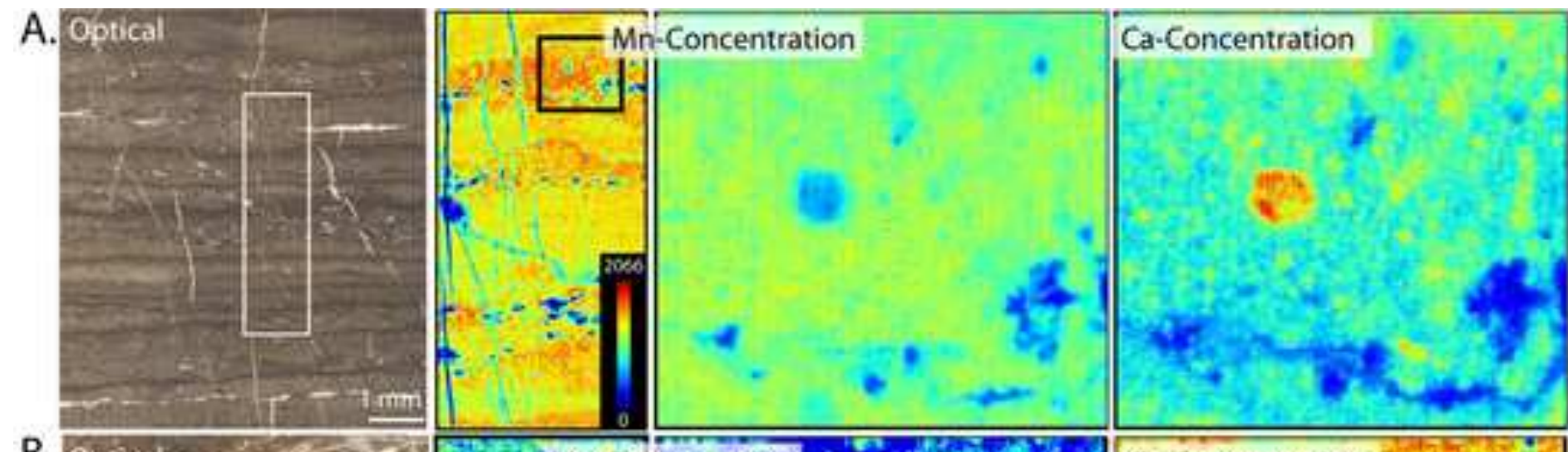

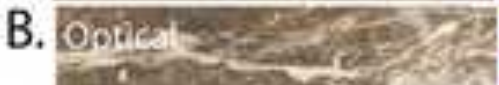
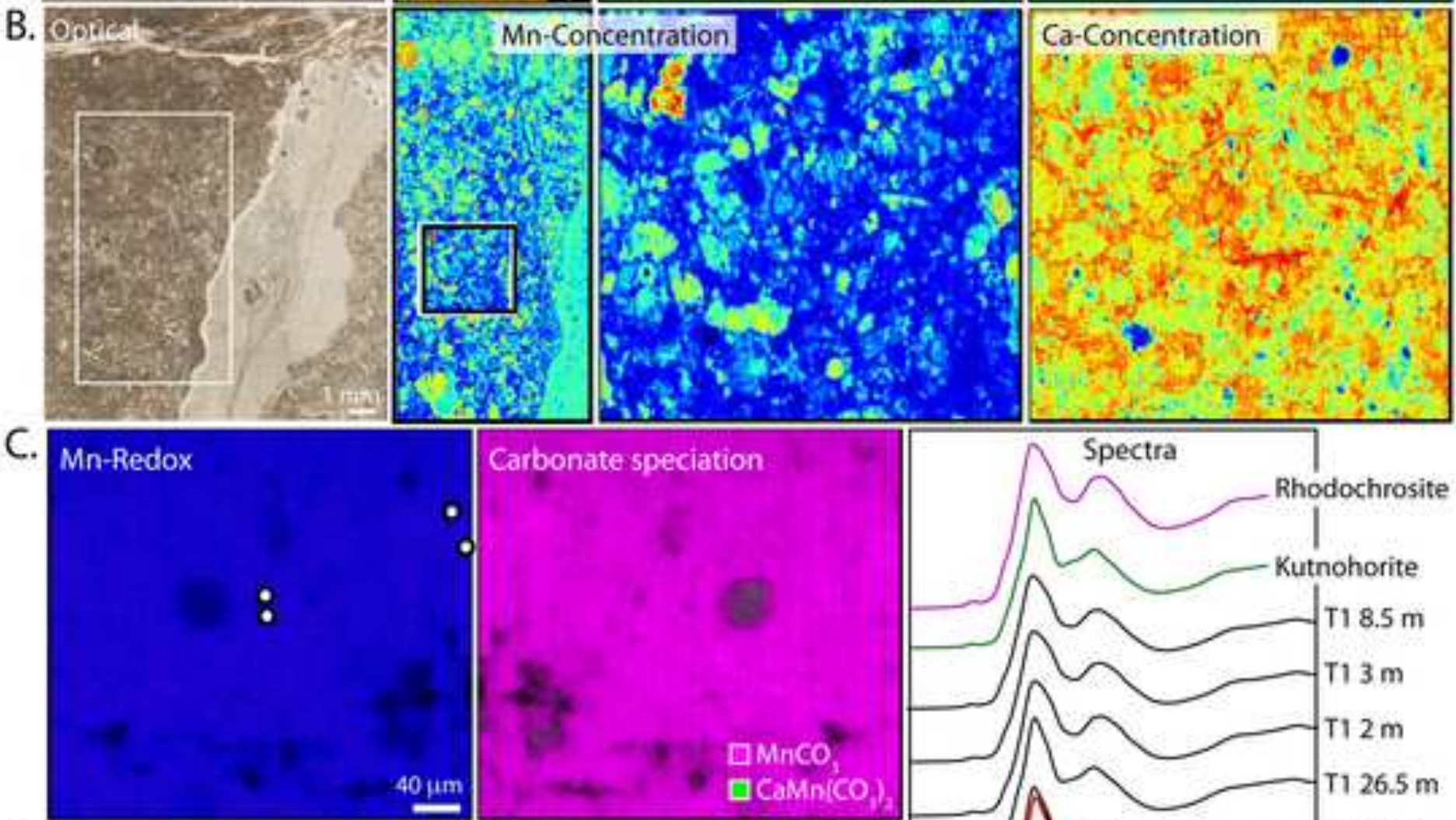

Carbonatespeciation

D. Mn-Redox
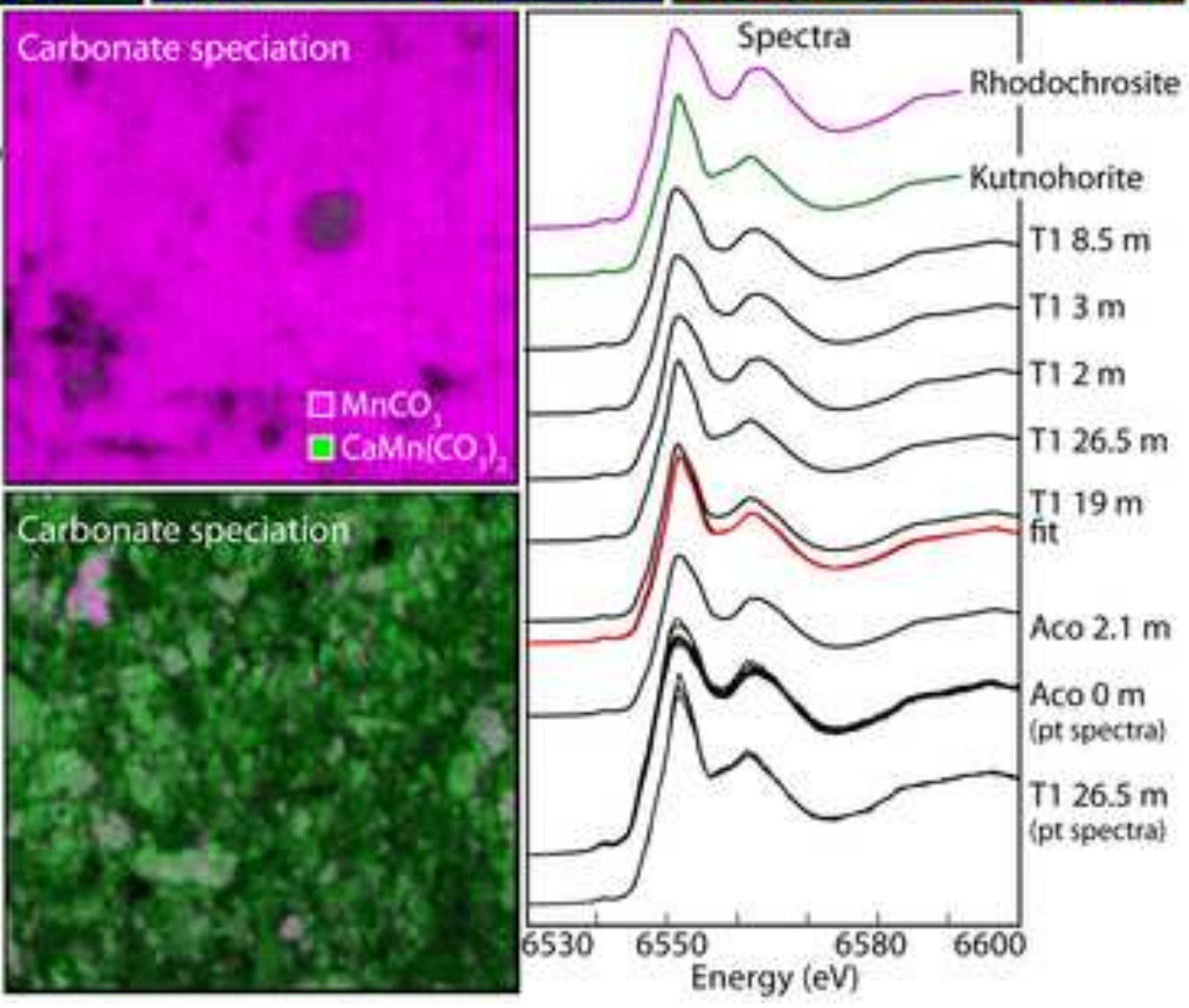

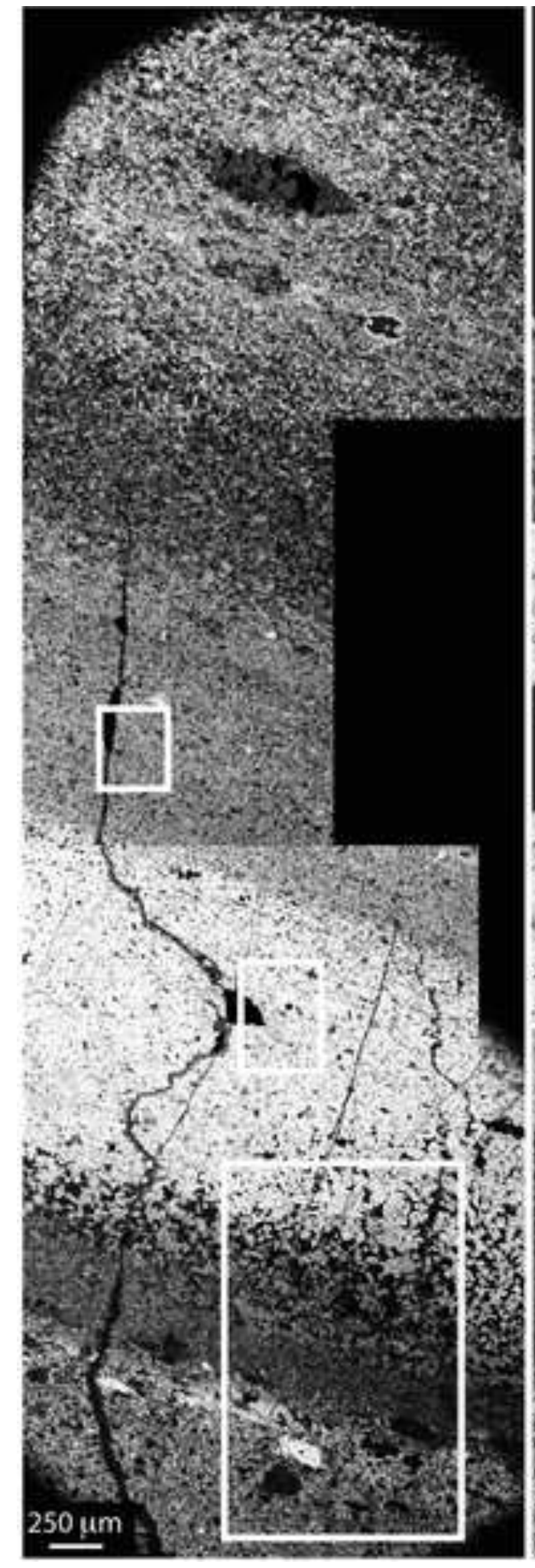
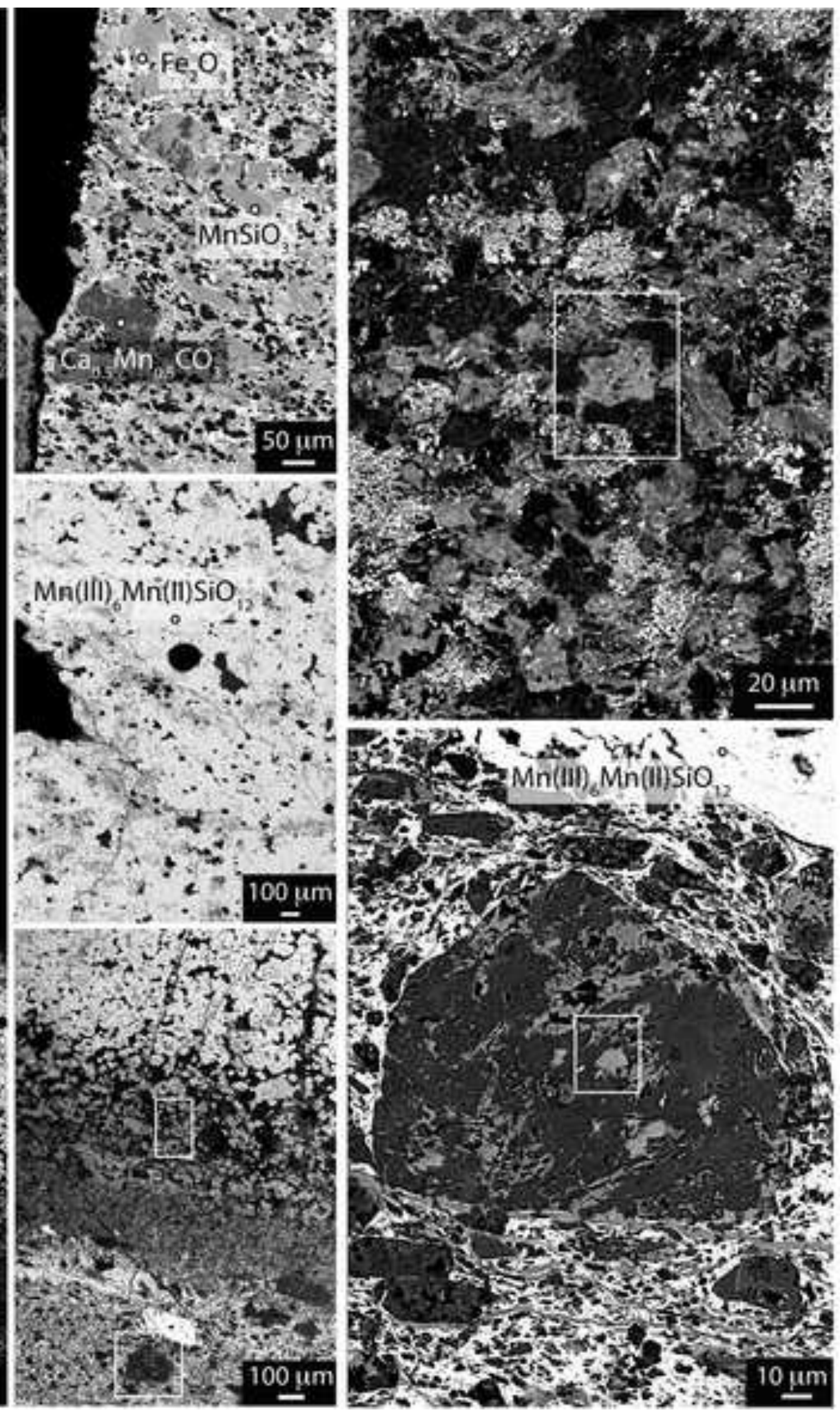
FigureA5

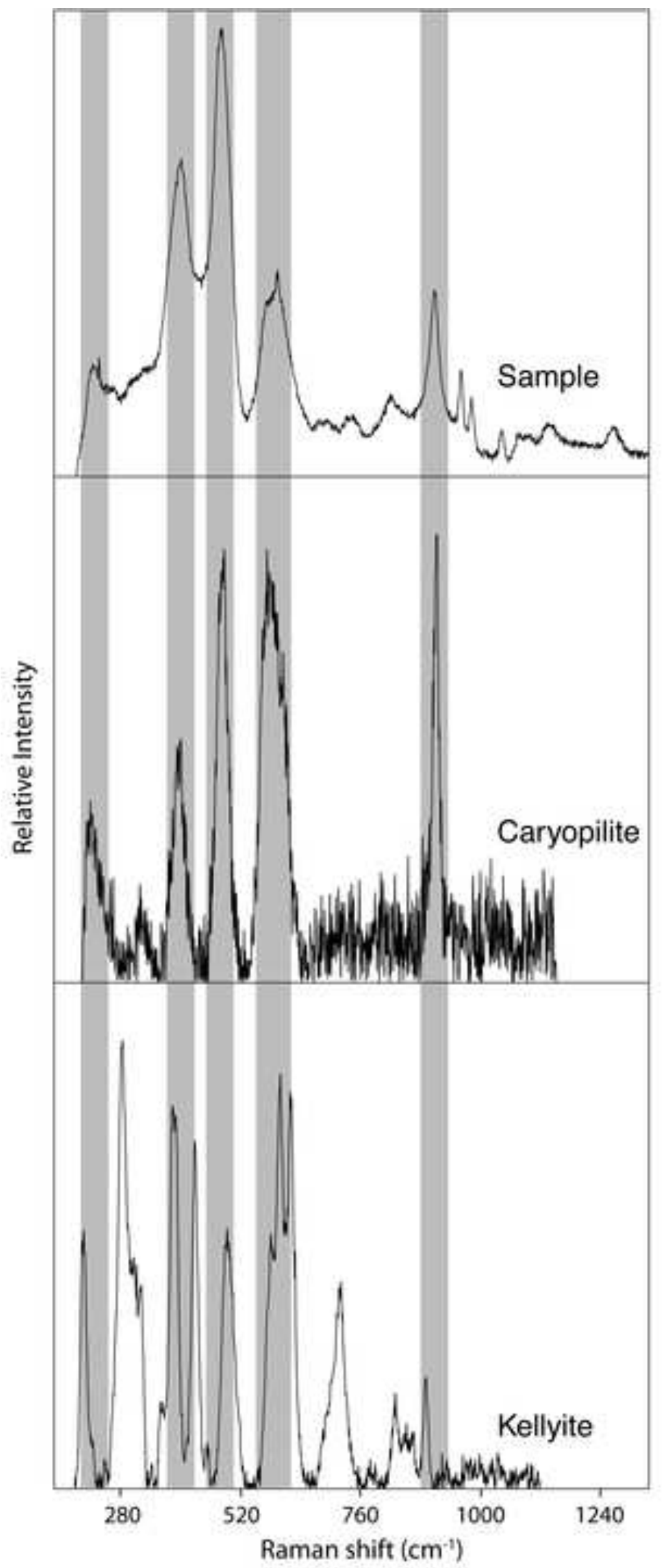




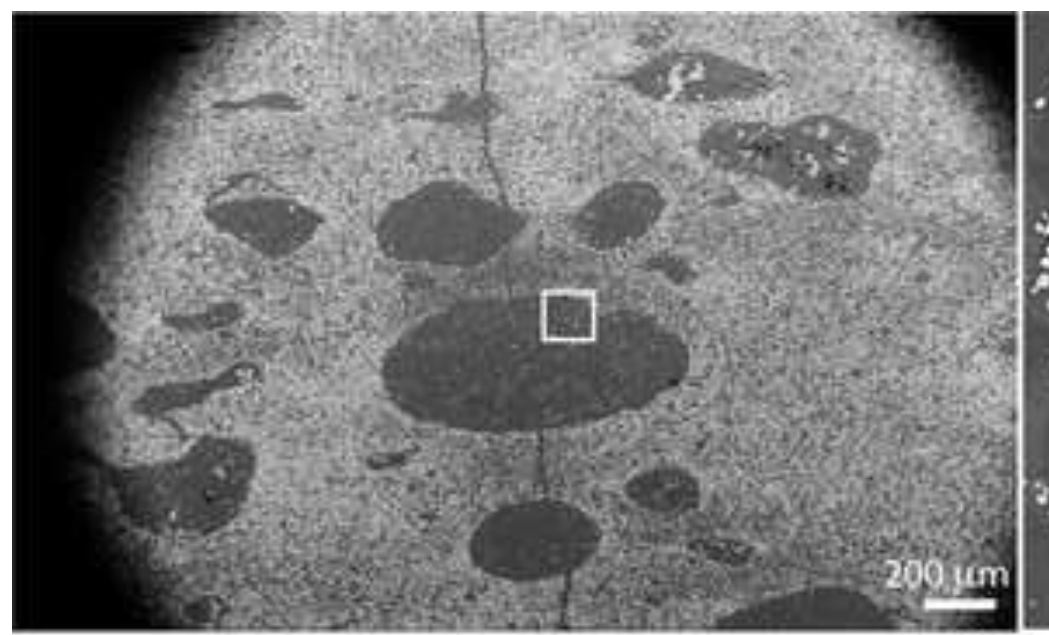

4.

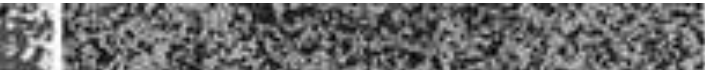

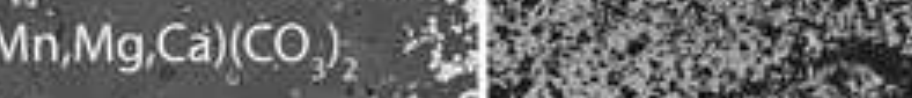

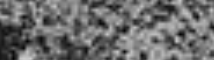

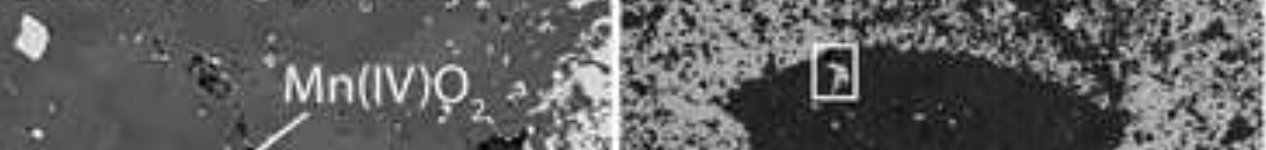

$\therefore$ : $\quad$ -

$\rightarrow$ s.

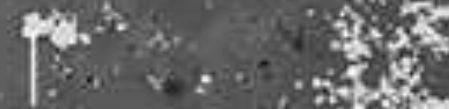

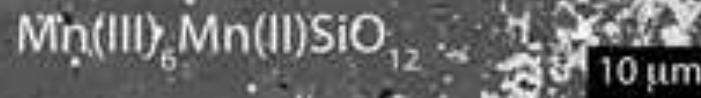

. 12 : $10 \mu \mathrm{m}$
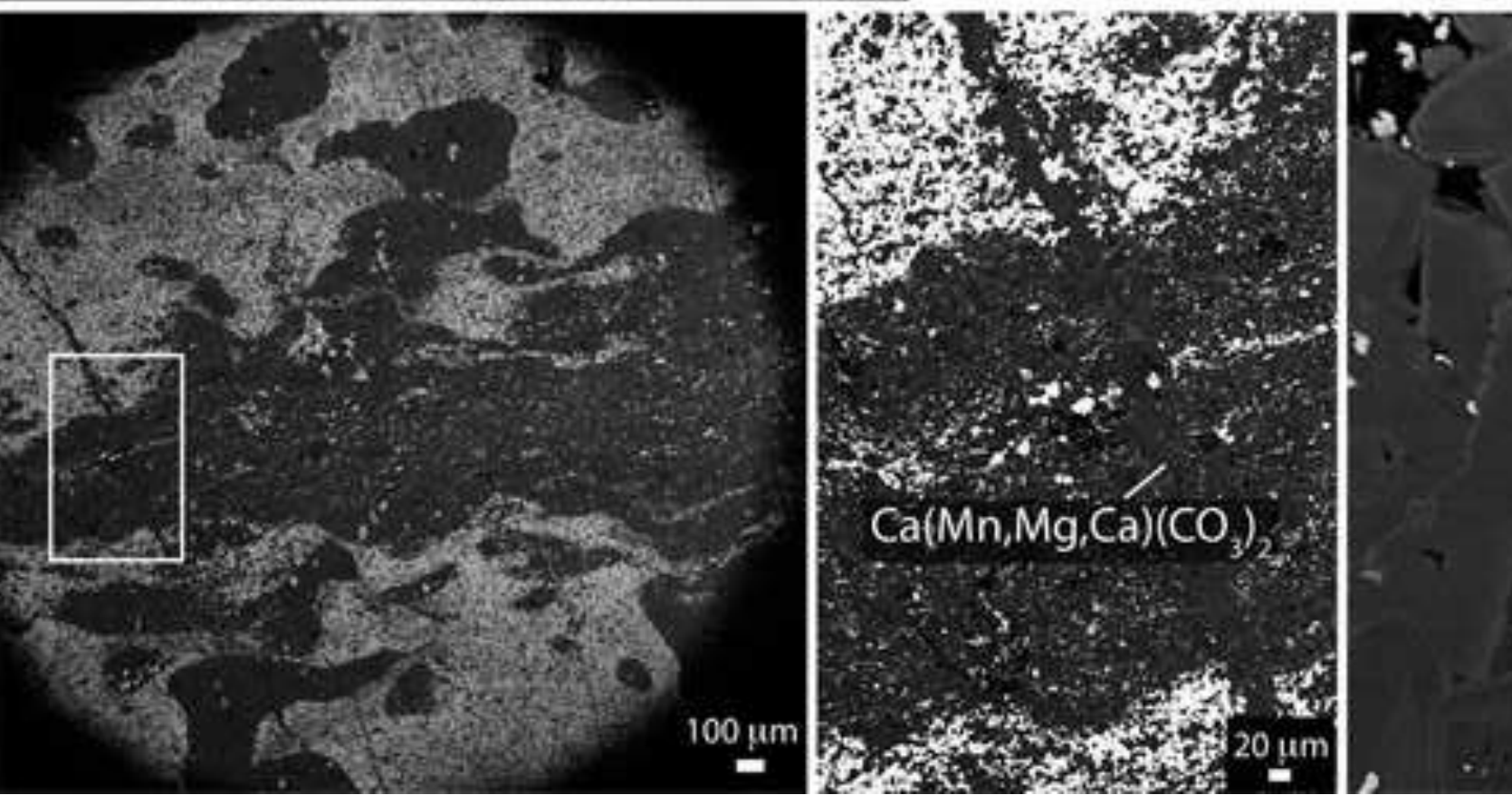

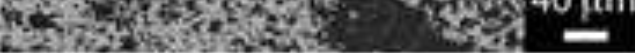

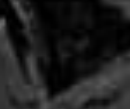

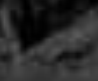

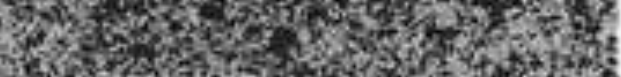

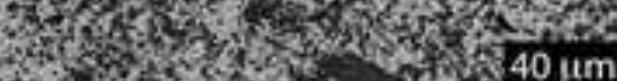

arese 40,20
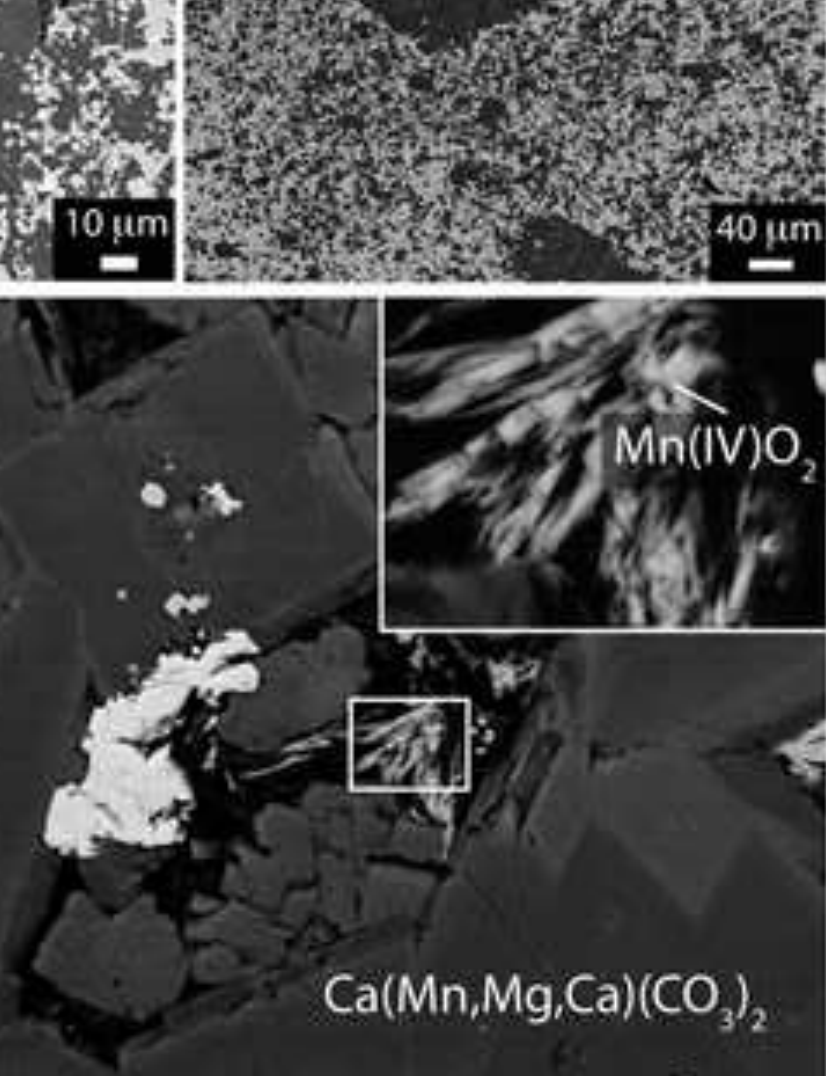

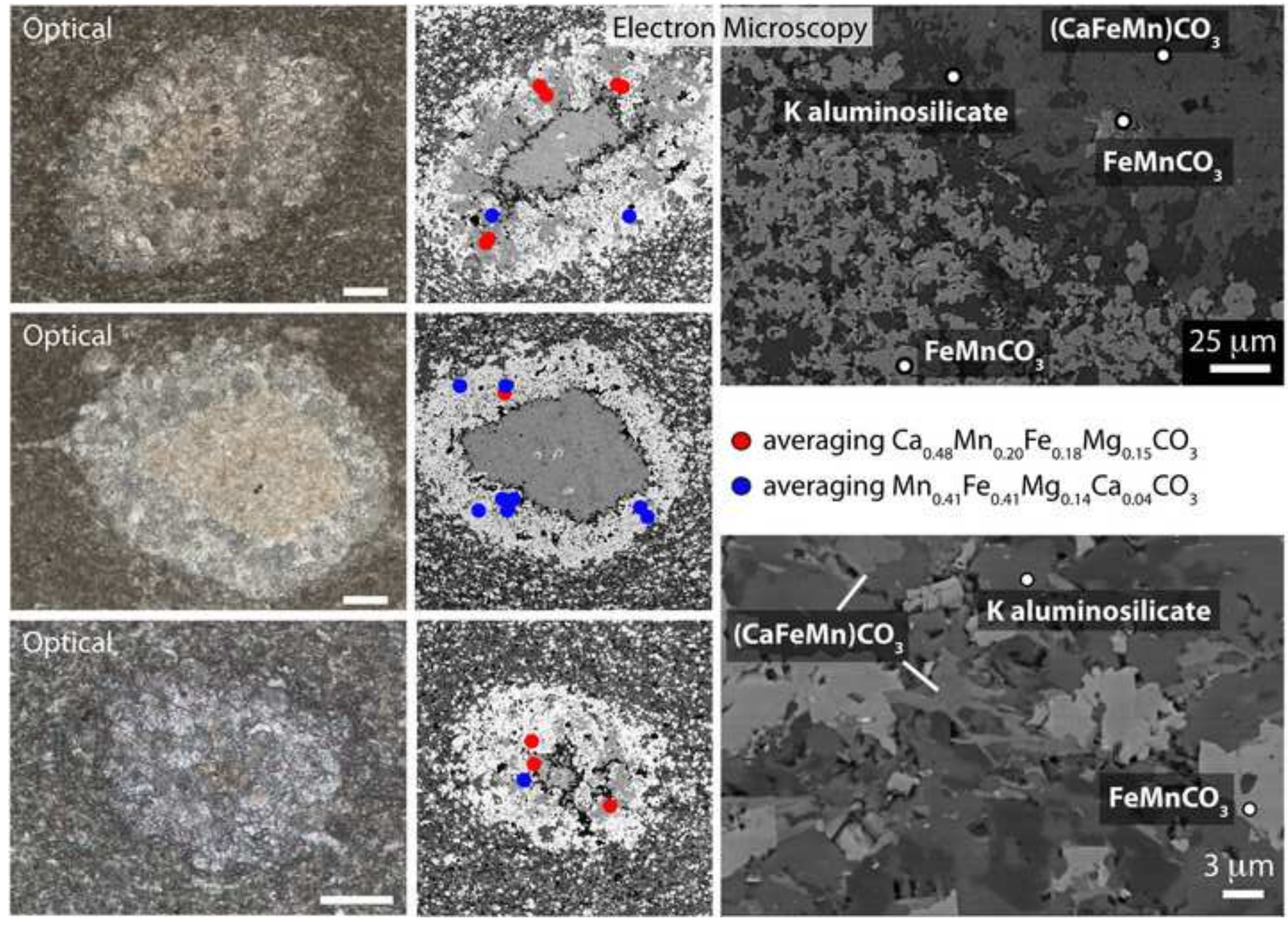